\title{
Inside Washington
}

\section{Christophen Wright \\ Assistant Director \\ ALA Washington Office}

Despite caustic observations from White House staff about congressional schedules, the House and Senate are in fact working at breakneck speed this spring.

ALA and the administration have already told the two appropriations subcommittees their conflicting stories about the need for federal library money, and action on a bill appropriating FY 1976 funds for education programs is imminent. Indeed, events are moving so quickly the congressional staff predict that money may get appropriated even before the fiscal year begins!

However, with library funding the topic of the hour in the ALA Washington Office, any. thing said in print today is likely to be changed by a conversation tomorrow. Therefore we ask your indulgence for one month while we wrestle with our numbers.

\section{News From the Field}

ACQUISITIONS

- The papers of the late Whitney M. Young, Jr., the civil rights leader, have been presented to Columbia University, it was announced recently. In recognition of this gift from his widow and the Whitney M. Young, Jr. Memorial Foundation, Columbia has renamed the library of its School of Social Work in Mr. Young's honor. The receipt of the papers makes Columbia the center for research on Mr. Young and his work in the civil rights movement.

The Young papers, 100,000 items covering the period from 1958 to his death in 1971 , focus primarily on his activities in the Urban League. The papers' documentation of $\mathrm{Mr}$. Young's tenure as executive director of the Urban League from 1961 to 1971 is particularly significant for Columbia because of the historic tie between the University and the Urban League. The concept for the establishment of the Urban League in 1911 came from faculty members and students of the New York School of Philanthropy, predecessor of Columbia's School of Social Work.

The papers also cover Mr. Young's involvement in a multitude of causes and events, including poverty, planned parenthood, law enforcement, black business meetings, a White House conference, and congressional hearings.

"In adding the Whitney M. Young, Jr. papers to its manuscript collections, Columbia helps perpetuate the achievements and aspirations of a great American," said Dr. William J. McGill, president of Columbia. "We welcome the papers because of their singular value as a resource for scholars and students concerned with the substance and process of social change in twentieth-century America."
- The Alfred C. Berol Lewis Carroll Collection has been donated to the Elmer Holmes Bobst Library at New York UNIversity by Mrs. Alfred C. Berol and her son, Kenneth R. Berol.

Assembled over several decades by the late Alfred C. Berol, this collection of the books, letters, manuscripts, and photographs of Lewis Carroll (C. L. Dodgson) is undoubtedly one of the finest of its kind. All of Carroll's extensive and varied production is present, usually with presentation inscriptions from the author. The collection contains an example of the famous 1865 "suppressed" edition of Alice in Wonderland in proof copy. There are no less than eight presentation copies of The Hunting of the Snark. A special section is devoted to translations of Alice into foreign languages, some 40 volumes ranging from Russian through Swahili to Esperanto. The many manuscripts include an early volume called Useful and Instructive Poetry with colored illustrations. Carroll's letters, which approach 500 in number, include several long and important series, among them 28 to Mary Dodgson and 48 to Gertrude Chataway. There are also many significant letters to Carroll. Of particular interest are the 75 photographs taken by Carroll, who is now recognized as one of the great early masters of the art.

The acquisition of this collection makes the Elmer Holmes Bobst Library a major center for Lewis Carroll studies, especially as the collection also includes many documents he contributed to the field of mathematics-Dodgson's basic profession.

- The late comic actor Billy De Wolfe's personal collection of stage, screen, and television 
memorabilia has been donated to Special Collections at the Unrvensirx of Southern CaliFORNIA,

The unique collection which documents his half-century love affair with entertainment includes scrapbooks of newspaper clippings dating back to his first professional engagements in 1925 .

Stills and candid photographs illustrate his backstage life as well as his film and television performances in Dixie (1942), Blue Skies (1946), Tea for Two (1950), Lullaby of Broadway (1951), and "The Doris Day Show" for CBS.

The collection also includes the costume props Mr. De Wolfe used to create his most unforgettable character, Mrs. Murgatroyd, the frumpy, middle-aged teetotaling housewife who spends her anniversary drowning her sorrows in the corner tavern.

- Among the sixteenth-century continental books acquired this year by the Folger Library

\section{Dissertation Topics Sought}

The listing of new doctoral dissertation topics accepted in library and information science, routinely published on a quarterly basis in the "Research Record" column of the Journal of Education for Librarianship, is being expanded. The column editor, Dr. Charles H. Davis of the University of Michigan School of Library Science, reports that additional coverage will be provided at the suggestion of the American Library Association's Committee on Research, the Library Education Division's Research Committee, and individuals within the library research community. In the future, the column will announce topics voluntarily contributed from programs such as business administration, computer and information science, and education, provided that the projects are clearly related to library and information science. These announcements, which will include "author," working title, school affiliation, date of acceptance, and major adviser, will be merged with those already being received from participating graduate library schools. For ease of updating, the file of dissertation topics is maintained in machine-readable form. Participating schools and interested individuals are asked to help identify potential contributors by contacting the column editor. at the University of California, Berkeley is a slim volume relating to the divorce of Henry VIII and Catharine of Aragon. It is the De Causa Matrimonii Serenissimi Regis Angliae and was written by John Fisher, bishop of Rochester, who was Queen Catharine's confessor. Fisher was the only English bishop to stand firmly against Henry's machinations to dissolve his marriage in order to marry Anne Boleyn. Although many other Latin tracts written by Fisher were printed on the continent, particularly those opposing Luther, for obvious reasons this work could not have been printed in England. The only known edition is this Spanish printing done at Compluti (Alcala de Henares) in 1530.

Before his execution in 1535, Fisher confessed to having written seven or eight tracts on the subject of the divorce, but this seems to be the only printed one extant. In his preface to the reader, the printer, Miguel de Eguia states that he printed it at the order of Alfonso, bishop of Toledo, who had received the manuscript from Fisher. It is not included in the Wurtzburg 1597 edition of Fisher's Latin works, nor does any modern printing of the text exist. No copy of this work is located in the United States by the National Union Catalog.

Another book purchased dates from the first quarter of the sixteenth century. It is the first illustrated book on architecture, and the first illustrated edition of Vitruvius' De Architectura. Edited by Fra Giocondo da Verona, an architect who worked for Louis XII of France, the book was published in Venice in 1511 . Vitruvius' architectural work is the only one that has survived from Roman times and it had a great deal of influence on the buildings of the Renaissance. The handsome woodcuts show decorations such as columns and capitals, various mechanical devices, and plans for houses and public buildings such as theaters.

- Harper and Row has deposited with CoLUMBIA UNIVERSITY a massive collection of authors' contracts, letters, and books documenting publishing history in the nineteenth century, a time when the firm's predecessor, Harper Brothers, was the major publisher in New York.

The collection includes the contracts for Moby Dick, Trilby, Ben Hur, and The Ambassadors.

The entire collection has been placed in the Columbia Libraries' Special Collections. It contains more than 5,000 contracts, agreements, and letters, and nearly 3,000 first editions.

"The background not only of printing and publishing in New York but of the development of American culture in the nineteenth century will be found in these documents and records," said Kenneth A. Lohf, Columbia librarian for rare books and manuscripts. "Their availability at Columbia," he added, "will help assure their 


\section{Access to the World of Foundations \\ New revised edition of the definitive reference:}

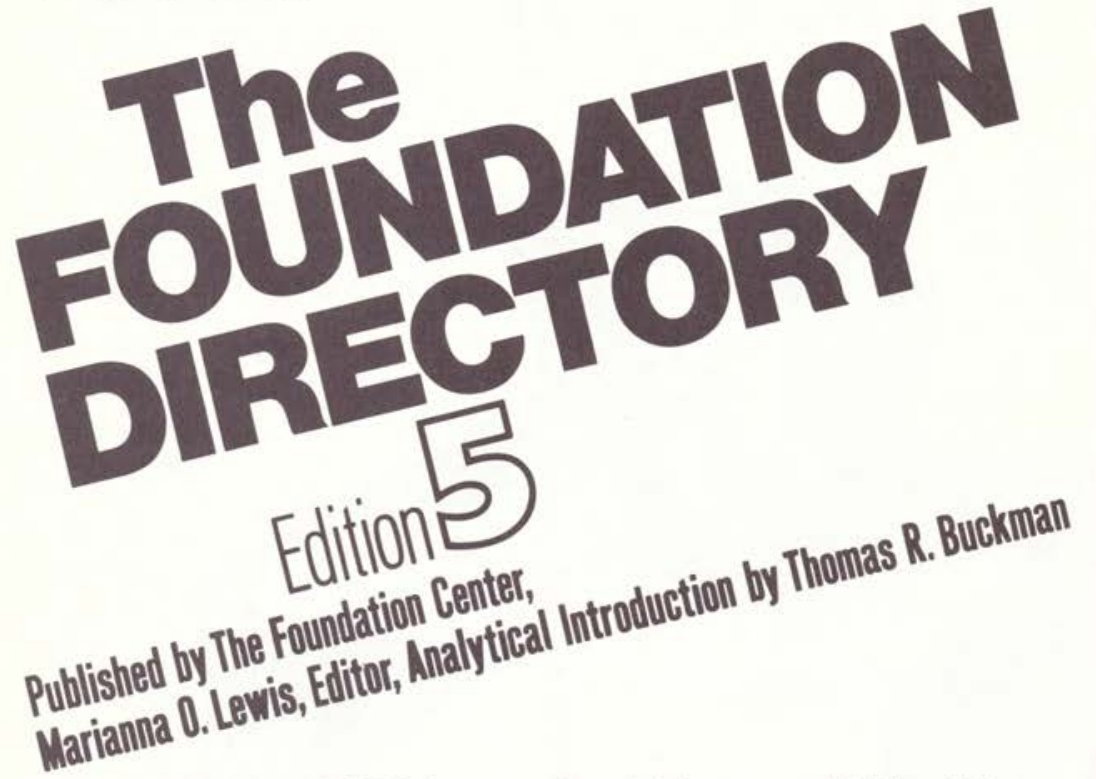

Complete listings of 2533 foundations with assets of $\$ 1,000,000$ or more or that award grants of $\$ 500,000$ or more annually. Each listing includes:
- Foundation nameand address
- Date and form of organization
- Names of donors
- Statement of purpose and de- scription of activities, including special limitations

- Names of officers and trustees or directors

- Financial data for the year of record (1972 or later)

Special features of Edition 5 include four indices (fields of interest, state and city location, personnel, and foundation name), a guide to the services and publications of The Foundation Center, and useful pointers on how to apply for grants.

540 pages, 15 tables,

$81 / 2 \times 11$ inches $\$ 30.00$ including four semiannual Supplements

Distributed by

\section{COLUMBA UNIVERSITY PRESS}

Address for orders:

136 South Broadway,

Irvington, New York 10533 


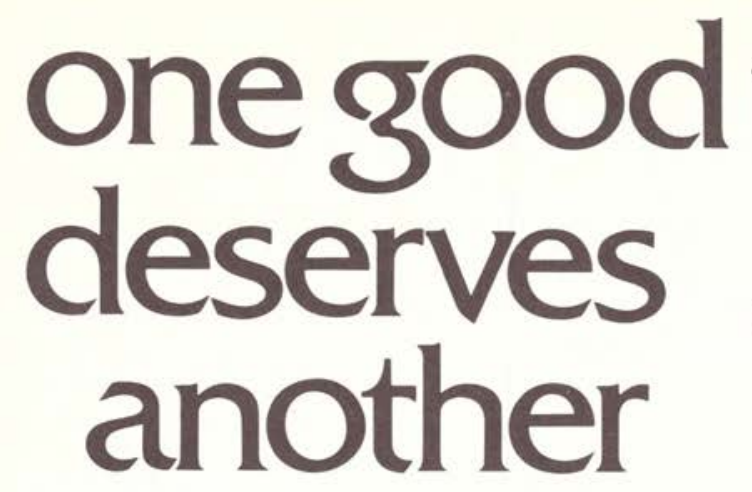

thing...

We designed this

READER CARREL just to hold our Xerox Model 1414

Microform Reader! These modular carrels can be grouped side to side,

back to back - any way that conforms to your floor plan.

Comfort-minded features

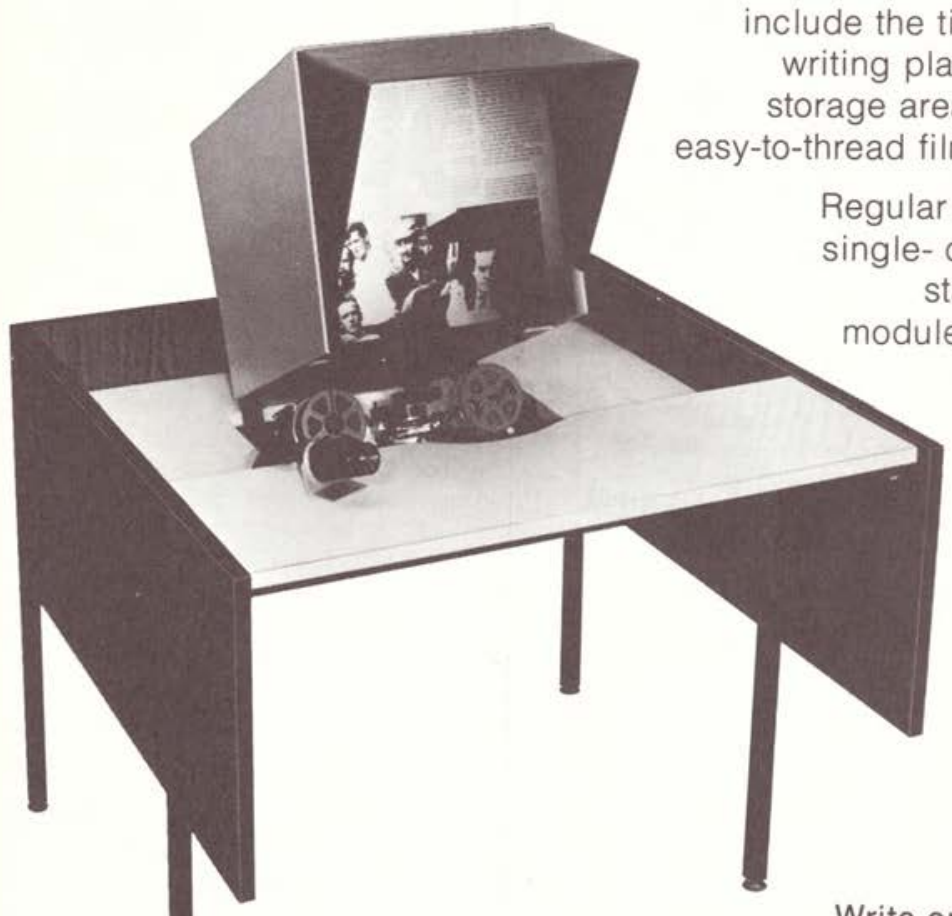

of the reader,

platform, recessed

storage areas, easy-to-see,

Regular or tall dividers, single- or double-faced starter and adder modules, two finishes.

Priced from $\$ 125$ to $\$ 375$.

Write or call our

Equipment Coordinator for details.

Xerox University Microfilms

300 North Zeeb Road

Ann Arbor, Michigan 48106 
usefulness to students and scholars who study the complex relationships among authors, publishers and printers."

The Harper contracts collection joins the Harper and Row publishing archives for 19351965 given to Columbia in 1972, as well as other publishing collections at Columbia: the files of Random House, W. W. Norton, Pantheon Books, and M. Lincoln Schuster. Columbia's research resources in American literary history are among the largest in this country and include the files of prominent authors and literary agents.

The Harper contracts now available for research at Columbia cover the period from 1817, when Harper Brothers began publishing, to 1900. The contracts include those with:

William Jay in 1833 for a biography of his father, John Jay, first chief justice of the United States and a 1764 graduate of King's College, Columbia's name then.

Herman Melville for Moby Dick, Redburn, White Jacket, Mardi, Omoo, and Typee"The Melville contracts are national treasures," Columbia library officials said.

Commodore Matthew F. Maury for The Physical Geography of the Sea, the first textbook on modern oceanography.

Samuel L. Clemens for publication of his books after the bankruptcy of Clemens' previous publishing house, in which he had invested heavily.

Henry James for The Ambassadors, originally considered unpromising and shelved; it was finally published in 1903, with a chapter unwittingly omitted.

In addition, an unusual record of the publishing history of 3,176 Harper titles from 1817 to 1879 is now at Columbia. It is contained in a leather-bound ledger compiled by William $\mathrm{H}$. Demarest, cashier of the firm for forty-five years, who worked on the book for three years after his retirement in 1877 . It is the only comprehensive source of information on Harper publishing operations prior to the 1850 s, detailing such things as names of printers, type of paper used, advertisements, and number of copies printed. Several fires in Harper buildings in the 1850s destroyed other early records. Contracts survived the fires because they had been kept in a metal chest. Systematic records of printing history began being kept in memorandum books starting in the 1850 s, and these, too, are now at Columbia.

- A gift of great rarity, a Hebrew incunabulum printed in Lisbon in 1489, has been added to the University of Southern CaliforNIA, Los Angeles Library's Department of Special Collections. The volume, a commentary on the Pentateuch by Moses ben Nahman (also known as Nahmanides), is considered by many rare book experts to be the first book printed in Portugal, and it is certainly the first book printed in Lisbon.

Moses ben Nahman, who was born in Spain, ca. 1195, and died in the Holy Land, ca. 1270, was one of the great minds of Jewish scholarship during the Middle Ages. He was a rabbi, a codifier of Jewish law, an interpreter of talmudic writings, an exegete, a poet, a philosopher, a cabalist, and a practicing physician. $\mathrm{He}$ is known to have authored more than thirty works, of which the commentary on the Pentateuch (Perush ha-Torah) is held to be his masterpiece. The first edition of the book was published in Rome, about 1480; the volume presented to the library is the second edition. (The first volume of an English translation of the commentary appeared in New York in 1971.)

Hebrew incunabula seldom survived intact. Natural disasters, persecutions, and censorship left their marks on these volumes: they are usually water-stained, worm-eaten, and incomplete. The present volume is a rare example of $\mathrm{He}$ brew incunabula: it is only slightly stained and is almost complete. Fifteen leaves lacking (out of a total of 302) were restored in excellent facsimile, the margins of some leaves were repaired, and a number of half-lines were re-

\section{LIBRARY EDUCATION IS EVERYBODY'S BUSINESS ...}

We invite you to join in our exchange of ideas between library educators and practicing librarians, trustees and administrators.

Our concerns are your concerns! Are you interested in continuing education, for example? Become involved in the

\section{LIBRARY EDUCATION DIVISION}

\section{American Library Association 50 E. Huron, Chicago, III. 60611}

(If you've already joined ALA, you can still add LED to your membership for an additional \$15.) 
stored in exact pen facsimile. The binding, nineteenth-century blind-tooled leather over wooden boards, with catch and clasp, completely restored the volume to its original form.

The donor of this rare work is Dr. Felix Guggenheim, of Beverly Hills. Dr. Guggenheim has been active for many years in international printing and publishing, with which he has combined a strong interest in early typography and bookmaking. He has paid special attention to early Hebrew printing, and has been able to acquire for his private collection a number of interesting Hebrew incunabula and other rare publications.

- The Special Collections Department of the Library at the Univensity of California, Irvine, has received the Ralph Waldo Gerard collection of papers from his widow. The collection includes over 100 original manuscripts of articles and lectures, as well as Dr. Gerard's college papers and notes, personal and professional correspondence, research ideas and notes, draft reports of experiments, papers relating to his many travels and lectures, photographs, awards and memorabilia, and other ephemeral material.

Dr. Gerard (1900-1974) was one of the most productive and distinguished neurobiologists of his time. He pioneered work on problems concerning nerve metabolism and nerve conduction, electrical activity in the brain during sleep and the nature of brain waves, regeneration in the central nervous system, and the action of drugs and hormones on the functioning of nerve cells. He was deeply interested in the biological basis of mental illness, particularly schizophrenia, and challenged the accepted

\section{CLR Annual Report Available}

The Council on Library Resources (CLR) made twenty-nine new grants for projects in fiscal 1974 and monitored sixty-nine ongoing activities based on CLR commitments of earlier years, according to its 18th Annual Report.

Fred C. Cole, council president, expressed appreciation to the Ford Foundation in the report's introduction, calling the foundation's sixth grant to CLR- $\$ 6$ million for the three-year period beginning July 1 , 1974, bringing to $\$ 29$ million Ford's contributions to the council's work on behalf of libraries-" particularly notable since it was made at a time of financial stringency for foundations as well as other institutions."

Copies of the 18th Annual Report are available from CLR at no charge. theory that mental disease was purely psychological and cultural in origin.

Dr. Gerard was the author of nine books and over 700 articles. He also served as editor of several scientific journals including the Journal of Neurophysiology, Physiological Review, and the American Journal of Physiology. Dr. Gerard held administrative posts in both private and governmental institutions. He was chairman of panels at the National Science Foundation, the National Institute of Mental Health, the Office of Naval Research, and was a consultant to the chief of naval research, the Surgeon General, and the National Aeronautics and Space Administration. $\mathrm{He}$ was elected to the National Academy of Science and the American Acad. emy of Arts and Sciences, receiving honorary degrees from the University of Leiden (Holland), the University of St. Andrews (Scotland), McGill University (Montreal), Brown University, and University of Maryland. His career centered around professorships at four major universities: the University of Chicago, the University of Illinois, the University of Michigan, and the University of California, Irvine, where he served as professor of biology and was the founding dean of the Graduate Division, a position he held until his retirement in 1970 .

\section{G R A N T S}

- The Reference Aids Subcommittee of the Committee on Research Materials on Southeast Asia (CORMOSEA) of the UnIversity OF Ha. wAII Library invites application for financial assistance in completing reference tool projects on Southeast Asia. The subcommittee's primary interest is to encourage and stimulate new reference tools, such as guides, bibliographies, indexes, handbooks, directories, etc., pertaining to the individual countries of Southeast Asia or to the region as a whole. The subcommittee is interested in providing completion grants to those projects already under way which would require limited support for their completion.

The grant is modest, ranging from $\$ 250$ to $\$ 2,000$ per award. The grants are not intended to cover salaries for the author or compiler, but are designed to defray the costs of typist, supplies, postage, and research materials and the like.

Interested applicants should include the following information in their request:

1. The proposed title of the project and the name (s) of the author (s)/compiler(s)

2. Statement of the need and the significance of the project

3. Statement of the purpose, scope, and status of the project

4. Methodology or procedure of the project 


\section{Personal background}

a. Academic qualifications, Southeast Asian experience, and present position

b. Linguistic skills

c. List of publications of the applicant

6. Proposed budget

a. The amount of financial aid requested from CORMOSEA

b. Breakdown of use of CORMOSEA aid

c. The sources of other aid

7. Plan for publication

a. Estimated date of completion

b. Commitment, if any, from any publisher to publish the proposed work

The deadline for the submission of the proposal is August 15, 1975. The awards will be announced in late October 1975. The proposal or request for further information should be addressed to: Shiro Saito, Chairman, Reference Aids Subcommittee, CORMOSEA, University of Hawaii Library, 2550 The Mall, Honolulu, HI 96822.

- The Maurice and Laura Falk Library of the Health Professions of the University of Pitrsburgh has received a $\$ 20,000$ grant from the Maurice Falk Medical Fund for the establishment of the F. Sargent Cheever Historical Library Fund. The fund honors Dr. Cheever, who retired last summer as vice-chancellor for the health professions at Pitt and president of the University Health Center of Pittsburgh.

The income from the fund will be used exclusively for the restoration, preservation, and improvement of items in the historical collection and for acquisitions to the collection housed in the Historical Collection Room opened in the library in 1974.

The grant was announced by Nathan J. Stark, vice-chancellor for the health professions, and Dr. Carroll Reynolds, director of the Falk Library.

In his letter awarding the grant, Philip B. Hallen, president of the Maurice Falk Medical Fund, stated, "The Trustees of the Maurice Falk Medical Fund are pleased to be able to honor Dr. Cheever in this fashion, because of his continued interest in the development of the historical collection." He also expressed hope that the establishment of the fund will attract substantial gifts from other individuals and groups interested in the history of medicine and the health professions.

The library has a substantial collection of historical materials on the health professions, including many valuable rare volumes and facsimile reproductions of ancient works, as well as more modern studies in the field. Among the rare books in the collection are two copies of the 1543 edition of Andreas Versalius' classic work on anatomy, De Humani Corporis Fabri$c a$, and an incunabulum (a book published be- fore 1500): Joannes Arculanus' Expositio in Avicennae Canonis. The library also serves as a repository for the archives and memorabilia of the Pittsburgh Academy of Medicine.

Construction of the Historical Collection Room, which opened last summer, was also made possible by grants to the Falk Library from the Maurice Falk Medical Fund.

\section{MEETINGS}

MAY 22-24: The twentieth annual meeting of the Midwest Academic Libharians ConferENCE will be held at the Ohio State University Libraries, Columbus, Ohio. The theme will be "Magic and Libraries." Contact Rita Hirschman, Main Library, Ohio State University, Columbus, OH 43210, for information and registration materials.

MaY 23: The spring meeting of the Delaware Valley Chapter, ACRL will be held at Haverford College, Haverford, Pennsylvania, at 1:00 p.m. The program, $U+S E=R:$ User + Sensitivity $=$ Relevant Library Service will feature Alphonse F. Trezza, executive director of the National Commission on Libraries and Information Science, as main speaker.

Workshops on the following topics will be held: (1) Psychology of Reference Service, (2) Making Cataloging Relevant, (3) Administrative Ingenuity, (4) Special Needs for the Researcher, (5) Book Selection for Whom? and (6) Circulation: Friend or Foe?

The day will also include tours of the Haverford Library and/or campus, and dinner on campus. For further information contact: Mary L. Walters, Langston Hughes Memorial Li-

\section{Replacement Collection Sought}

The College of Emporia discontinued classes in January 1974. The institution reopened September 1974 under new affiliation and is now known as The Way College of Emporia.

In the interim period, all the library books were sold. The Library Search Committee is therefore making inquiries about colleges and academic institutions that have closed or are about to close. Basically the committee is searching for a replacement library with a liberal arts collection. If such a library becomes available or is now available, please notify the Library Search Committee, School of Library Science, The Way College of Emporia, Emporia, KS 66801. 
brary, Lincoln University, PA 19352; (215) 932-8300.

May 27-31: The Middee East Librarian's Association will be holding a workshop on Options in Cooperative Middle East Librarianship in Ann Arbor, Michigan. The workshop is being sponsored by the ACRL/SSRC Joint Committee on the Near and Middle East.

For further information contact: John A. Eilts, President, Middle East Librarians Association, Near Eastern Division, University of Michigan Library, Ann Arbor, MI 48104. See the April CoRL News for further details.

JUNE 8-12: The sixty-sixth annual conference of the Special Libramies Association will be held at the Palmer House, Chicago, Illinois. The theme of this year's conference will be "Systems and Networks: A Synergistic Imperative." For further information, contact: SLA, 235 Park Ave. South, New York, NY 10003.

June 15-20: XX SALALM. The XX Seminar on the Acquisition of Latin American Library Materials will convene in Bogota, Colombia, at the invitation of Dr. Jorge Rojas, director of the Instituto Colombiano de Cultura.

\section{ACRL Cassette on Criteria for Promotion and Tenure}

The second in a series of audiocassettes produced and distributed by the Association of College and Research $\mathrm{Li}$ braries is now available for purchase from the ACRL office. The tape, entitled ACRL Seminar on Criteria for Promotion and Tenure in Academic Libraries, records a meeting, held in the fall of 1974, of fifteen untenured members of the University of Oregon Library Faculty.

The meeting was called to discuss, in the frankest possible manner, the ramifications of recent developments in higher education-e.g., steady-state or declining budgets, tenure quotas, and higher performance standards for promotion and tenure-which would affect the professional careers of the members present. The discussion covers all the issues involved in full faculty status, with particular emphasis on its responsibilities.

The ninety-minute cassette is available at a cost of $\$ 6.50$ from the ACRL office, 50 E. Huron St., Chicago, IL 60611. Checks should be made payable to the American Library Association.
Address inquiries concerning the program to Mrs. Emma C. Simonson, Latin American Librarian, Indiana University, Bloomington, IN 47401. Other questions may be directed to Mrs. Pauline P. Collins, Executive Secretary of SALALM, Secretariat, University of Massachusetts Library, Amherst, MA 01002. See the January C $\mathcal{U} R L$ News for more information.

JUNE 15-27: The Catholic University's library science department will host the third annual Institute on the Library and the Governmental Process.

Conducting the sessions will be Robert E. Frase, consulting economist and author of $\mathrm{Li}$ brary Funding and Public Support, and Alphonse F. Trezza, executive director of the National Commission on Libraries and Information Science.

Participants in the library science institute may receive three graduate credits. Tuition and fees total $\$ 215.00$. The program is open to qualified practicing librarians and graduate students in library science. For more information write: Dept. of Library Science, The Catholic University, Washington, DC 20064; (202) 6355085. See the April CURL News for further details.

June 22-25: Law Libranians. The American Association of Law Libraries will meet in the Century Plaza Hotel, Los Angeles, California. More information from AALL, 53 W. Jackson Blvd., Chicago, IL 60604.

June 23-27: Manpower Planning. The theme of the 1975 annual management course organized by the London and Home Counties Branch of the Library Association will be "Library Manpower Planning in the '70s and '80s." The course will be held at Woburn, Bedfordshire. Inclusive residential course fee is $\$ 95.00$.

Full details are available from David Baynes, 61, Crossways, Crawley, Sussex, U.K. See the April C\&RL News for further details.

JUNE 25-28: "Eighteenth-Century English Books Considered by Librarians and Booksellers, Bibliographers and Collectors" is the theme of the 1975 RaRe Books and Manuscripts Preconference to be held in San Francisco.

The preconference is sponsored by the Rare Books and Manuscripts Section, Association of College and Research Libraries, a division of the American Library Association. Donald D. Eddy, associate professor of English and librarian of the Department of Rare Books, Cornell University, is chairman of the Program Planning Committee. 
Further information and registration details can be obtained from Beverly P. Lynch, Executive Secretary, ACRL, 50 E. Huron St., Chicago, IL 60611; (312) 944-6780. See the April $C \& R L$ News for further details.

June 26-28: Collective Bargaining. "Collective Bargaining in Higher Education: Its Implications for Governance and Faculty Status for Librarians" will be the topic of a preconference meeting in San Francisco. Sponsored by the ACRL Academic Status Committee, the program is part of the continuing effort of the committee to provide information which will help librarians in understanding and evaluating status and governance issues.

Further information and registration forms are available from: Beverly P. Lynch, Executive Secretary, Association of College and Research Libraries, 50 E. Huron St., Chicago, IL 60611 .

JUne 29: The ALA SRRT Task Force on WOMEN will be holding an all-day women's conference in San Francisco. The conference will include morning workshops on organizing for change, an afternoon panel discussion, and an evening celebration along with an exhibit area for women's groups and presses. For information about attending the conference or arranging for an exhibit contact: Helen $\mathrm{B}$. Josephine, 2569 Hilgard Ave., Berkeley, CA 94709; (415) 849-3804

July 1: The Census Subcommittee of the RASD/RTSD/ASLA Public Documents Committee will be sponsoring a meeting at the ALA Annual Conference in San Francisco on the 1980 Population and Housinc Censuses. The program will begin with a speaker from the Census Bureau, followed by small group discussions and a concluding summary. The Census Bureau is already working on the 1980 official census form; during the group discussion period, each person present will have an opportunity to make suggestions for additions, deletions, and changes to it. In addition to the form, the committee feels that, as librarians, we should pay special attention to access tools, visual aids, teaching aids, and other reference materials that the bureau could develop or improve. However, all suggestions will be welcomed and nothing is too minor.

A questionnaire will be sent from the committee to a sample of reference and documents librarians to determine areas of interest for the discussion groups to concentrate on. Anyone else who wishes, especially if he won't be attending the meeting, is invited to send suggestions and comments to Ms. Alice Wickizer, Head, Documents, Indiana University Li- braries, Indiana University, Bloomington, IN 47401 .

JuLy 21-23: A futurist principal of a middle school, Almon G. Hoye, Anwatin Learning Center, Minneapolis, and an innovative college dean, Robert J. Toft, Grand Valley State Colleges, Allendale, Michigan, will keynote the University of Wisconsin-Stout's tenth annual Educational Media and Technology ConFERENCE to be held in Menomonie, Wisconsin.

Hoye's topic "Let's Do More With What We Have!" is appropriately aimed at media specialists in a downtrend economy. Ten years ago Hoye made a number of predictions concerning what education would be like in 1984 . Most of his predictions have become a reality during the first ten years.

Toft administers College "IV," part of a fouryear, undergraduate, liberal arts, state-supported college which does not possess a schedule of classes, a time base, a grading system, or a course structure. His topic "Individualized Instruction: Implementation Strategies For An Entire College" is based upon his experience of utilizing a curriculum matrix of auto-instructional learning packages which are entirely selfpaced.

Further information may be obtained by contacting Dr. David P. Barnard, Dean of Learning Resources, University of Wisconsin-Stout, Menomonie, WI 54751.

\section{Rare Steinbeck Is Stanford's Four Millionth}

The Stanford University Library has acquired its four-millionth book, the complete archives of John Steinbeck's Cannery Row. A gift from Mr. and Mrs. Warren R. Howell and the W. R. Hewlett Foundation, the archive includes Steinbeck's original pencil manuscript, typescript, and galley proofs corrected by the author, in addition to Steinbeck's own copy of the first edition.

The Cannery Row archive has many annotations. On one galley, for example, Steinbeck's editor has noted the repetition of a phrase, "time stops and examines itself." Steinbeck's response to the repetition was, "intended-but if it outrages the sensitive ear and horrifies the understanding - in other words, if you are afraid of the New Yorker, cut out the second one."

The archive is part of the "rich treasure" of Steinbeck material that went on exhibit at the library on April 6. 
July 22-25: The fifth Cranfield Conference on Mechanised Information Storage and Retrueval Systems will be held at Cranfield Institute of Technology, Cranfield, Bedford, England.

The conference will be fully residential and the cost, including accommodation, meals, and the conference dinner will be $\$ 82.00$. Full details of the program, together with application forms, are available from Cyril Cleverdon, Cranfield Institute of Technology, Cranfield, Bedford MK 43 OAL, England.

August 4-15: The Catholic University's library science department's third annual INsTItute on Federal Library Resources will be directed by Frank Kurt Cylke, chief of the Division for the Blind and Physically Handicapped at the Library of Congress.

The program is open to qualified practicing librarians and graduate students in library sci-

\section{WHRC Seeks Support}

The Women's History Research Center will receive $\$ 10,000$ in $1974-75$ revenue sharing funds if the center can raise $\$ 30,000$ in donations and standing orders from libraries to microfilm its extensive collection on women and law. As previously reported in the February 1975 issue of CURL News, the WHRC has been unable to obtain funds to operate its library, and the library's collections are being dispersed. One thousand five hundred of the 2,000 files from the Topical Research Library are at the Archive of Contemporary History, University of Wyoming, Laramie. The center is seeking the $\$ 30,000$ to complete the microfilming of the women and law collection so it can be available for anywhere, free, on microfilm before the original files are taken over by the University of Wyoming. Section I of the law collection, Law/General: ERA, credit, divorce, child care, sports, etc., is now available on microfilm at $\$ 30.00$ per reel from WHRC. Personal donations and standing orders from libraries are needed to support the microfilming of thirty-two remaining reels on politics, employment, education, rape, prison and prostitution, and black and third world women. The Women's History Research Center, 2325 Oak St., Berkeley, CA 94708 will be grateful for your support and happy to supply further information. ence. Participants in the institute may receive three graduate credits. Tuition and fees total $\$ 215.00$.

For more information contact the Department of Library Science, The Catholic University, Washington, DC 20064; (202) 635-5085. See the April C\&RL News for further details.

August 10-16: Librany Administration. An executive development program for library administrators will be offered at Miami University, Oxford, Ohio, by Miami's School of Business Administration. The program is designed to assist library administrators in improving their managerial effectiveness.

This will be the twenty-first executive development program presented by Miami University for library administrators within the last seven years. Because of its emphasis on general management principles and techniques, the program is of value to all kinds of library administrators-public, university, special, technical, corporation, etc.

The fee of $\$ 295.00$ includes all program expenses: tuition, instructional fees, cost of all reading materials and other handouts, personalized notebooks, plus room and board. Anyone interested in attending should contact the program director: Dr. Robert H. Myers, School of Business Administration, Miami University, Oxford, $\mathrm{OH}$ 45056. See the April CdRL News for further details.

August 24-28: The Urban and Regional Infonmation Systems Association (URISA) will hold its thirteenth annual conference at the Washington Plaza Hotel in Seattle, Washington. The theme will be "The Role of Information Systems Technology in Community Management."

Octorer 23-26: The Oral Histony Association will hold its tenth National Colloquium on Oral History at the Grove Park Inn in Asheville, North Carolina.

The theme for the colloquium will be "Oral History Comes of Age: The Tenth National Colloquium on Oral History."

The program chairperson for the colloquium is Thomas Charlton, Baylor University, and the workshop chairperson is Waddy Moore, State College of Arkansas.

For further information about the Oral History Association write Ronald E. Marcello, Secretary, Box 13734, North Texas Station, North Texas State University, Denton, TX 76203.

November 9-12: Chassification Systems. The University of Illinois Graduate School of Library Science will hold a four-day institute at Allerton Park, the university's conference center near Monticello, Illinois, about twenty- 
five miles southwest of Champaign-Urbana. The institute for 1975, the twenty-first in the series, is scheduled to be on "Major Classification Systems."

With the centennial of the first edition of Dewey's classification system coming in 1976, the faculty of the school decided to devote next fall's institute to a study and evaluation of classification systems. The cosponsor of the 1975 Allerton Institute will be the Forest Press, Albany, New York, publishers of the decimal classification. The institute, however, will concern itself not only with Dewey but with other major classification systems being used in English-speaking countries.

A brochure describing the program in detail will be issued in June 1975. Individuals interested in receiving the brochure and registration information should write to Mr. Brandt W. Pryor, Institute Supervisor, 116 Illini Hall, Champaign, IL 61820.

\section{MISCELLANY}

- The Hans P. Kraus Collection of 162 manuscript items relating to the history and culture of Spanish America in the colonial period (1492-1819) has been made fully available in microfilm form and may be used by qualified researchers in the Library of Congress' Manuscript Reading Room. The original manuscripts will be available only for special research needs. Scholars may order positive microfilm copies of the Kraus collection from the Photoduplication Service, Library of Congress, Washington, DC 20540. The positive microfilm may also be borrowed on interlibrary loan from the chief, Loan Division, Library of Congress.

The collection of Spanish-American manuscripts was donated to the library in 1969 by Hans P. Kraus of New York City, the wellknown collector and bibliophile, and head of the firm Hans P. Kraus, dealers in rare books and manuscripts. The collection includes letters and documents relating to the explorers Amerigo Vespucci, Giovanni de Verrazzano, and Alvar Nuñez Cabeza de Vaca. Included in the collection are contemporary colonial writings that document the government of New Spain (Mexico), the workings of the Inquisition, taxation and economic conditions in the colonies, Spanish relationships with the Indians and the French, and the loss of parts of the Spanish empire to American encroachment.

- The Asian american Librarians Caucus (AALC) is an organization seeking affiliation with the American Library Association and other national organizations. The major pur* poses of the AALC are to provide a forum for discussion of problems and concerns, the exchange of ideas by Asian American librarians, and to recruit qualified Asian American candidates to enter the library/information science profession. Any librarian of Asian ancestry presently employed in the United States, citizen or noncitizen, may elect to become a personal member of the Caucus. The term "Asian American" will be broadly applied to include anyone who considers himself as such.

The newly organized Asian American Librarians Caucus had two planning meetings at ALA Midwinter in Chicago. Both meetings were well attended, and the general enthusiasm indicated the need for such an organization. During the meetings, several working committees were formed and are chaired by the following Asian American librarians: Constitution Committee (Tamiye Trejo), Publicity Committee (Ken Yamashita), Program Committee (Henry Chang), Membership Committee (Janet Suzuki), Liaison to other groups (Y. T. Feng), Bibliography (Julie Ho, Susan Tu, Toyo Kawakami, and Momoko Murakami). The AALC needs volunteers to work on each committee. Please write or contact the committee chairperson or any of the AALC officers.

The meeting schedule to be requested for the San Francisco Conference to be held on June 29, 1975 is:

Sunday, June 29, 2:00-4:00 p.m., San Francisco Program Steering Committee Meeting

Monday, June 30, 9:00-12:00 a.m., Program Meeting

Wednesday, July 2, 2:00-4:00 p.m., Business Meeting

Thursday, July 3, 10:00 a.m.-12:00 noon, Steering Committee

The theme of the San Francisco program will be: "Contributions of Asian Americans to the United States." The San Francisco program

\section{Warning Sticker Offered}

The $U^{*} N^{*} A^{*} B^{*} A^{*} S^{*} H^{*} E^{*} D$ Librarian has designed a special device to alert readers that they may be dealing with outdated materials. An octagonal orange sticker with the warning "CAUTION. Information in this book may be out of date. Ask a librarian" is now available through The $U^{*} N^{*}$ $A^{\circ} B^{*} A^{\star *} S^{\circ} H^{\circ} E^{\circ} D$ Librarian, GPO Box 2631, New York, NY 10001. Ten sample copies are being offered at no cost with additional labels costing five cents apiece. UL cites "crunchy times" and the inability of many libraries to purchase the most recent editions of given works as a major reason for using these labels. 


\section{Brand-new 1975 edition of "the only comprehensive guide to.... active sources of advanced knowledge" - Catholic Library World RESEARCH CENTERS DIRECTORY} FIFTH EDITION

A Guide to University-Related and Other Nonprofit Research Organizations Established on a Permanent Basis and Carrying on Continuing Research Programs. Edited by Archie M. Palmer. 1,056 pages. L.C. No. 74-11841. ISBN 0-8103-0453-8. \$68.00.

With its usefulness proved by the four previous editions, Research Centers Directory now appears in a thoroughly updated fifth edition containing over 6,000 entries, of which 1,200 are new. The basic details furnished in $R C D$ entries enable users to discover and contact specific sources of current information on virtually all aspects of man and his world.

A typical entry gives: 1) name of research unit, 2) address, 3) phone number, 4) director's name, 5) year founded, 6) status: affiliated, independent, etc., 7) sources of support, 8) size and type of staff, 9) annual budget, 10) principal fields of activity, 11) special research facilities and their availability for use by outsiders, 12) media in which results are published, 13) serial and periodic publications, 14) seminars, conferences, courses, etc., 15) library facilities.

\section{EXTENSIVE NEW SUBJECT INDEX 19 CONVENIENT SECTIONS IN ALL}

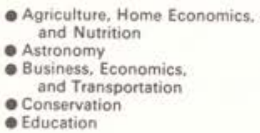

- Social Sciences, Humanities. and Religion

- Multidisciplinary Programs - Research Coordinating Offices - Subject Index

- Institutional Index - Index of Research Centers

\section{Periodical supplements to RCD \\ NEW RESEARCH CENTERS}

Inter-edition supplement, with binder for new subscribers, ISBN 0-8103-0451-1. Subscription, $\$ 64.00$.

Issues of New Research Centers provide descriptive information-in the same format as RCD-5-on newly formed and newly found research centers. In addition, significant changes in status or more details on the activities of centers listed in the Directory appear in NRC, with cross-referencing to the original entries.

Order the Fifth Edition of Research Centers Directory and New Research Centers on Gale's 30-day free-trial plan. Standing orders for future editions will insure automatic delivery.

\section{GALE RESEARCH CO.}

BOOK TOWER - DETROIT, MICH. 48226

REVIEWERS'

COMMENTS ON PREVIOUS EDITIONS

"Recommended for all academic libraries and for large and medium-sized public libraries." - Bohdan S. Wynar,

American Reference Books Annual

"Recommended for purchase." Choice

"An invaluable reference work which should be available in all but the smallest libraries.... Important is the periodic supplement New Research Centers."Kenneth F. Kister, Library Journal

'This valuable directory is kept up to date by New Research Centers." Wilson Library Bulletin 
meeting scheduled for June 30,1975 , at 9:00 a.m. at the ALA Annual Conference will be moderated by Dr. Henry C. Chang, library director, College of the Virgin Islands. The program will feature as keynote speaker Dr. Harry H. L. Kitano, professor of social welfare and sociology at UCLA. Other panelists include Professor Sucheng Chan, Ph.D., of the Asian American Studies Program, University of California, Berkeley; Mrs. Julia Li Wu, commissioner of the National Commission on Libraries and Information Services (topic: "In Search of True Identity: An Overview of School Library Resources with Reference to Asian Americans and Their Cultural Heritage"); Mr. Arthur Ignacio, chief librarian of the University of California Department of Ethnic Studies Library; and Ms. Sunok Chung, library specialist, Orange County Public Library, California.

If anyone is interested in receiving any information regarding the AALC or wishes to volunteer to run for an office of the Caucus, please write or contact Dr. Henry Chang, Kingshill P.O. Box 84, St. Croix, U.S. Virgin Islands 00850; (809) 778-1620; or Ms. Janet Suzuki, 5630 N. Sheridan \#13E, Chicago, Illinois 60660 ; (312) 334-6162.

- Effective in February 1975, the School of Library Science at the University of Southenn California will add to its curriculum the degree Doctor of Library Science. The D.L.S. is a professional rather than a research degree as is the Ph.D. The D.L.S. provides librarians with an alternate route to the doctorate. It closely links educational programs to career objectives and stresses problems of analysis, planning, and evaluation of library operations. The D.L.S, program is, in particular, directed toward librarians in middle management positions. Areas of specialization include advanced administration and management techniques, reference and technical services, information science, and others.

An applicant to the D.L.S. program must hold a master's degree in library science from

\section{Networks Proceedings No Longer Available}

The ACRL office has exhausted its limited supply of copies of the published proceedings of the University Libraries Section 1973 preconference on The University Library's Role in Information Networks. Orders and checks for the proceedings, entitled Networks and the University Library, are being returned to the sender. a library school offering a master's program accredited by the American Library Association and must have completed two or more years of relevant professional experience in a library or closely related environment after the receipt of the master's degree.

Prospective students interested in working toward the D.L.S. degree should write to Dean Martha Boaz, School of Library Science, University of Southern California, Los Angeles, CA 90007 for further information and admission materials.

- The National Commission on Libraries and Information Science will ask Congress this spring to appropriate the full $\$ 3.5$ million authorized for a White House Conference on Library and Information Services in order to expedite conference planning.

The commission's chairman, Dr. Frederick Burkhardt, told participants at the January conference of the American Library Association that President Ford's signing the White House Conference bill into law on December 31, 1974 , now elears the way for conference preparations.

The first step, said Burkhardt, will be to assemble the names of persons who should serve on the twenty-eight-member advisory committee on the conference. According to law, the committee will consist of the chairman and at least three members of the National Commission, five persons designated by the Speaker of the House of Representatives, five designated by the president pro-tempore of the Senate, and fifteen persons named by the president. Burkhardt urged librarians and others concerned with the conference to write their members of Congress and the White House with suggestions of committee members.

Outlining the potential budget for the White House Conference and its supporting state conferences, Burkhardt said the commission would ask Congress to appropriate the full $\$ 3.5$ million authorized by the law when Congress considers a second supplemental appropriations bill this spring. The entire sum must be allocated now, said Burkhardt, because work must begin immediately if all fifty states are to plan and hold their own conferences before a White House Conference is held in 1977. "These state conferences," he added, "are the key to communicating a sense of urgency to the national conference."

Describing the anticipated timetable for conference preparations, Commission Executive Director (Designate) Alphonse F. Trezza told the ALA meeting that the commission hopes to hire a chief program planner and to add four new staff positions so coordination of White House Conference and state conference activities can start. 


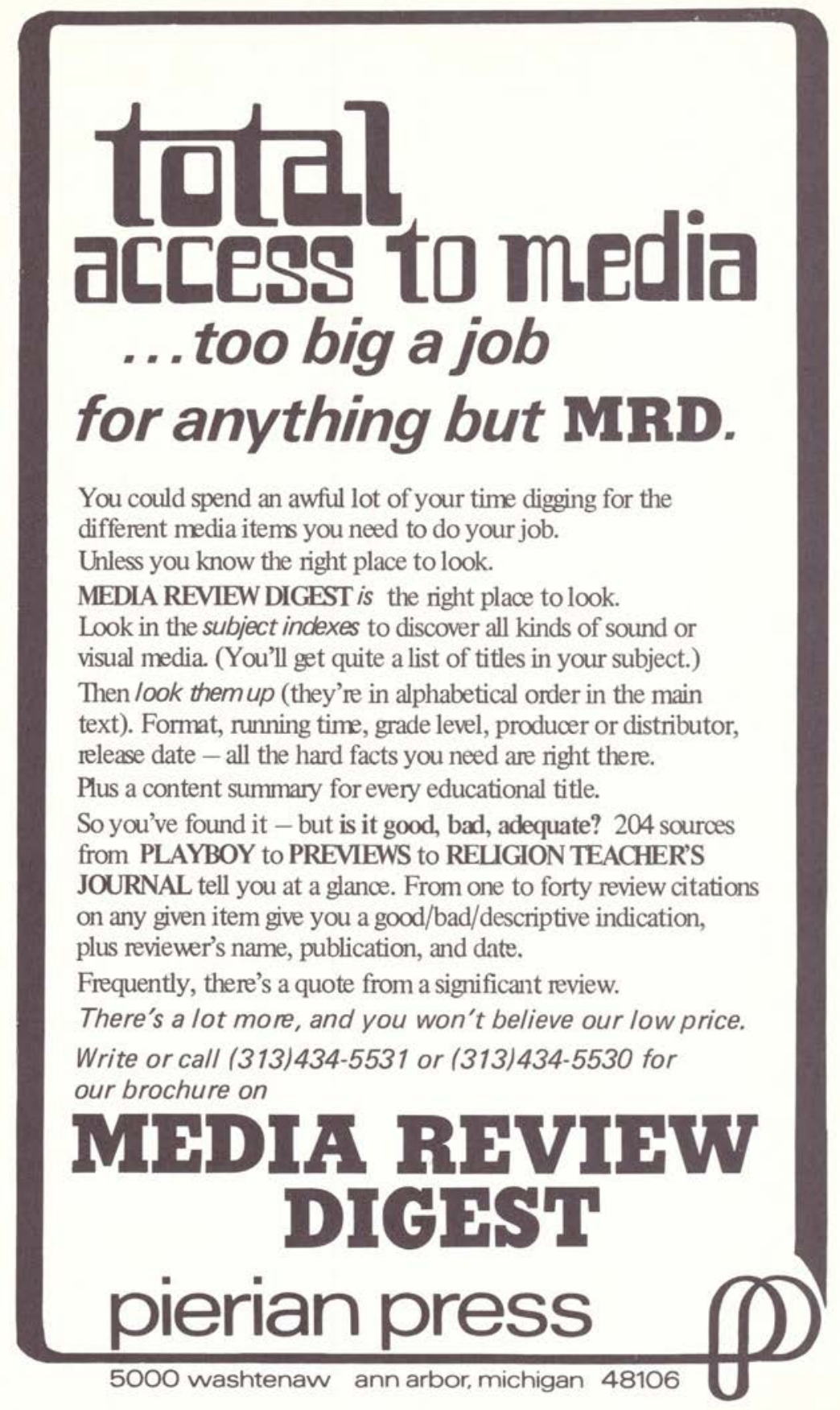




\section{The Snstitute for Scientific Onformation}

\section{invites you to tour}

\section{its facilities eluring}

your Bicentennial

visit to Philadelphia.

$I S I^{\circledR}$ welcomes the many visitors who will be coming to Philadelphia in 1975-1976 for the nation's Bicentennial.

While you're in the historic area, we hope you'll use the opportunity to tour ISI-we're located just a block from Independence Hall and the Liberty Bell. We'd like to show you how Current Contents ${ }^{\circledR}$, the Science Citation Index ${ }^{\circledR}$, and a variety of other information serv-

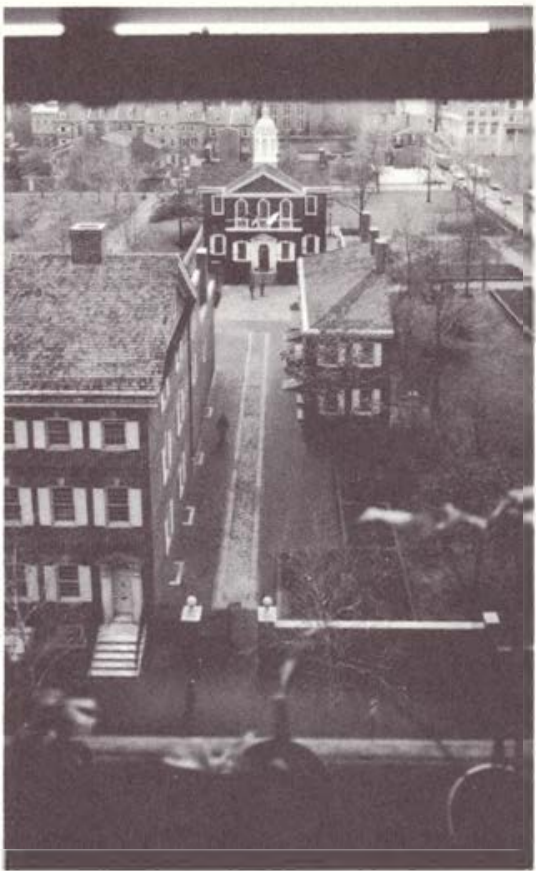

Carpenters Hall-where the First Continental Congress mel in 1774-from ISI ices are produced.

At ISI you'll view an orientation film, take a guided tour through important work areas, and get a chance to ask ISI personnel about our operations and services. ISI tours will start at 2 p.m. every Tuesday and Thursday (except holidays) beginning April 1, 1975. Because the number of places on each tour must be limited, tours will be run on a reservation only basis.

Avoid disappointment-make your reservations now. Use the coupon or phone Jean Sprissler at ISI.

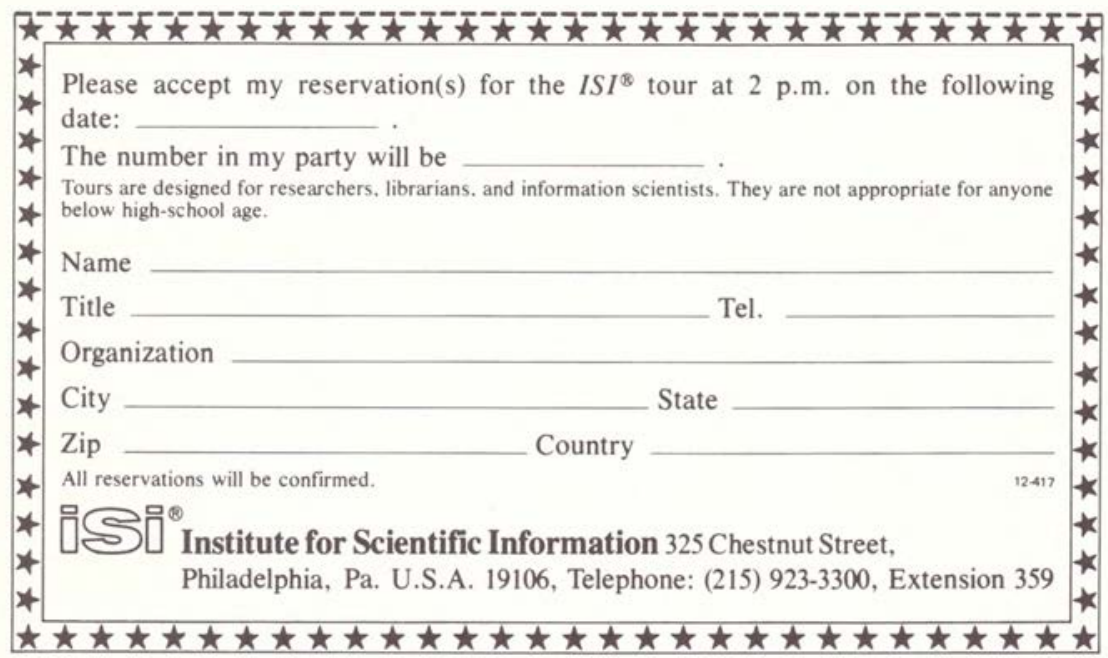




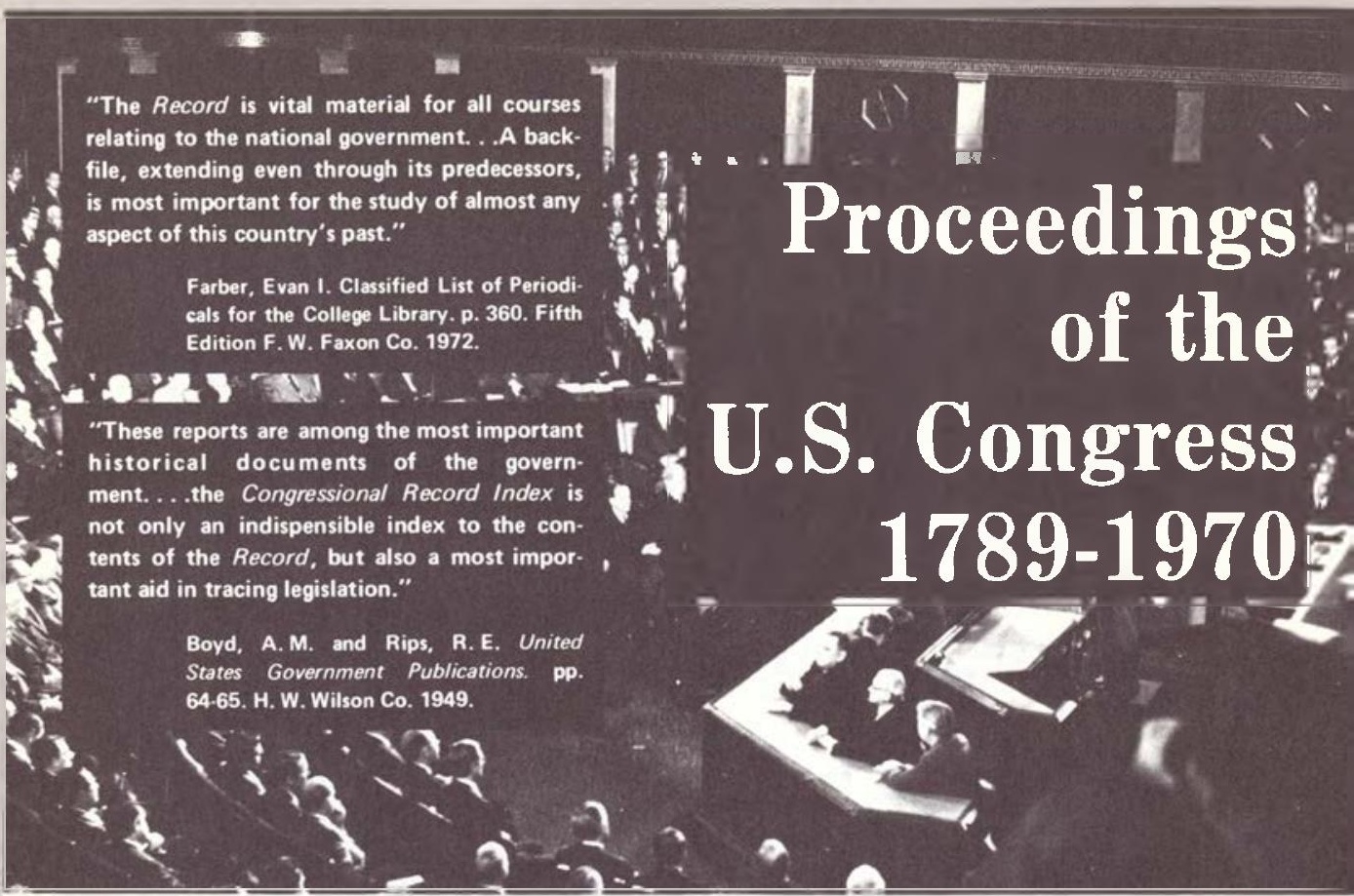

\section{The Index Volumes}

\section{- a major reprint publishing project in themselves}

The actual production of 110 large bound volumes, containing indexes to all 226 regular and special sessions of the first 91 Congresses, can in itself be considered a substantial republication program. There are an estimated 80,000 pages in the set, with most in a two column format. Although there are variations in format that make it difficult to estimate the total number of entries, conservative projections place the figure at well over one million

Each Congressional Record Index consists of two parts, as follows:

Part One: Index to Proceedings

These indexes list entires by subject and author, and also by names of individuals and of committees. Several uniform sub-headings are used throughout. As stated by Boyd and Rips (in addition to their quote from U.S. Government Documents, which appears on the cover of their brochu1e), "If a definite reference to the material in the Congressional Record is wanted, it is a fairly simple matter to locate it by looking under subject or name."

\section{Part Two: History of Bills and Resolutions}

This section gives the full title of each bill or resolution and indicates all actions taken upon it. Committee report numbers are given, as are references to the Congressional Record pages on which the progress of each measure is recorded. Index entries appear at various stages from the time a measure is introduced, through when it is reported, amended, debated, passed (or rejected), signed or vetoed by the President, and finally given a law number.

Individual Volumes May Be Purchased Separately By Libraries Wishing To Complete Their Holdings.
USE THIS CONVENIENT PR

\begin{tabular}{|l} 
Proceedings of the \\
U. S. Congress, \\
Sets and Sub-Sets \\
\\
\hline 1. Annals of Congress: \\
1st Congress through 18th \\
Congress, 1st session (1789-1824) \\
2. Register of Debates: \\
18th Congress, 2nd session through \\
25th Congress, 1st session (1824-37) \\
3. Congressional Globe: \\
23rd Congress through 42nd \\
Congress (1833-73) \\
4. Congressional Record: \\
43rd-54th Congress (1873-97) \\
55th-65th Congress (1897-1919) \\
66th-77th Congress (1919-42) \\
78th-88th Congress (1943-1964) \\
89th-91 st Congress (1965-70) \\
CR Series: 43rd-91st Congress \\
(1873-1970) \\
Totals
\end{tabular}

All sets ars available for delivery within 30 days of receipt of order with the exception of certain index volumes which have been sold out and are in the process of being reprinted. 


\section{THE DUAL MEDIA CONCEPT SAVES MONEY AND SPACE WITHOUT SACRIFICING RESEARCH EFFECTIVENESS}

The complete set now contains 572 reels of microfilm, plus 110 index volumes and covers the following series.

* The Congressional Record (1873-1970)

* The Congressional Globe (1833-1873)

* The Register of Debates (1824-1838), and

* The Annals of Congress (1789-1824).

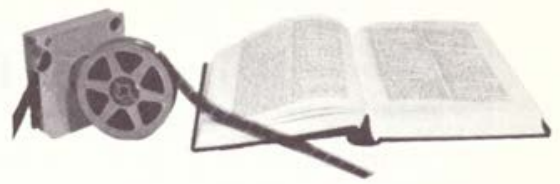

Together they comprise the only official narrative of the first 182 years in the history of the Legislative Branch of the U.S. Government.

As viewed by Evan Farber, who is Librarian at Earlham College as well as author of Classified List of Periodicals for the College Library and a member of the Institute's Editorial Advisory Board.

"Having the Proceedings of Congress available then, in the Dual-Media Edition, with the proceedings and appendices on microfilm and the Sessional Indexes and Histories of Bills and Resolutions in printed form (the Record is almost useless without its Indexes), means that libraries can now offer the wealth of this resource plus the convenience in book format, yet use a minimum of space and money."

Although other publishers offer the Congressional Record in micro-form, the discounts we offer on Dual-Media set purchases make our prices considerably below the amounts required to buy the separate index volumes from us and microfilm from any other group. (See the "Set Price per Reel" column in our price schedule at right.)

ICE SCHEDULE TO ORDER DUAL-MEDIA SETS FOR IMMEDIATE DELIVERY.

\begin{tabular}{|c|c|c|c|c|c|c|c|c|c|c|c|}
\hline \multicolumn{5}{|c|}{ Dual-Media Combinations } & \multicolumn{3}{|c|}{ Microfilm Only } & \multicolumn{4}{|c|}{ Index Volumes Only } \\
\hline & \multirow{2}{*}{$\begin{array}{l}\text { Price } \\
\text { per } \\
\text { Set }\end{array}$} & \multirow{2}{*}{\multicolumn{2}{|c|}{$\begin{array}{l}\text { Combined } \\
\text { Savings }\end{array}$}} & \multirow{2}{*}{$\begin{array}{c}\text { Set } \\
\text { Price } \\
\text { per Reel }\end{array}$} & \multirow{2}{*}{$\begin{array}{c}\text { No. } \\
\text { of } \\
\text { Reels }\end{array}$} & \multicolumn{2}{|c|}{ Prices } & \multirow{2}{*}{$\begin{array}{c}\text { No. } \\
\text { of } \\
\text { Vols. }\end{array}$} & \multicolumn{3}{|c|}{ Prices } \\
\hline & & & & & & per Set & Single Reels & & & ger Set & each \\
\hline$\$$ & 210.00 & $\$$ & 35.00 & $\$ 12.00$ & 10 & $\$ 155.00$ & $\$ 18.00$ & 2 & $\$$ & 90.00 & $\$ 46.00$ \\
\hline$\$$ & 119.00 & $\$$ & 16.00 & $\$ 14.00$ & 6 & $\$ 100.00$ & $\$ 18.00$ & 1 & $\$$ & 35.00 & $\$ 35.00$ \\
\hline$\$$ & 810.00 & $\$$ & 100.00 & $\$ 14.47$ & 38 & $\$ 650.00$ & $\$ 18.00$ & 6 & $\$$ & 260.00 & $\$ 47.50$ \\
\hline$\$ 1$ & $1,680.00$ & & 180.00 & $\$ 13.75$ & 48 & $\$ 840.00$ & $\$ 18.00$ & 23 & &, 020.00 & $\$ 47.50$ \\
\hline$\$ 2$ & $2,020.00$ & & 200.00 & $\$ 14.08$ & 71 & $\$ 1,200.00$ & $\$ 18.00$ & 23 & & 020.00 & $\$ 47.50$ \\
\hline$\$ 2$ & $2,400.00$ & & 240.00 & $\$ 13.95$ & 99 & $\$ 1,620.00$ & $\$ 18.00$ & 23 & & 020.00 & $\$ 47.50$ \\
\hline$\$$ & $4,100.00$ & & 430.00 & $\$ 14.48$ & 205 & $\$ 3,400.00$ & $\$ 18.00$ & 23 & & 130.00 & $\$ 47.50$ \\
\hline & $1,800.00$ & & 180.00 & $\$ 14.21$ & 95 & $\$ 1,530.00$ & $\$ 18.00$ & 9 & $\$$ & 450.00 & $\$ 52.00$ \\
\hline$\$ 11$ & $1,980,00$ & & 250.00 & $\$ 14.17$ & 518 & $\$ 8.590 .00$ & $\ldots$ & 101 & & 640.00 & $\ldots$ \\
\hline & $2,950.00$ & & 570.00 & $\$ 13.85$ & 572 & $\$ 9,495.00$ & $\ldots$ & 110 & & 025.00 & $\ldots$ \\
\hline
\end{tabular}

To: The United States Historical Documents Institute Inc.

1911 Fort Myer Drive, Arlington, Virginia 22209 (703) 525-6035

Please record our order for those segments of the Proceedings of the U.S. Congress which are circled on the above price schedule. 
BONWELL Charles C

BONWELL Charles C. Dept of Hist, Southeast Mo Si Coll, Cape Girardeau Mo 63701

BONWICH William T, Dept of Mktg, St Louis Univ, Se Louis Mo 63103 BONWIT Marianne, Dept of German, Univ of Cal, Berkeley Cal 94720 BONWITT Kenneth $\mathbf{L}$, Dept of Libr Sci, Miami-Dade Jr Coll, 11380 NW 27th Ave. Miami Fla 33167

BONY Jean V Dept of Hist of Art. Univ of Cal, Berkeley Cal 94720

BONYHARD Janet $F$, Dept of Phil, Mary Wash Coll, Fredericksburg Va 22401

BONYUN David A, Dept of Computer

Sci. Acadia Univ, Woltuille, N S Canada DO640

BONZELAAR Helen, Dept of Art, Calyin Coll, E Belt Line M37, Grand Rapids Mich 49506

BONZELET Joseph T, Dept of Law Enforcement, Coll of the Mainland. 8001 Palmer Hwy, Tex City Tex 77590 BONZYK Edmund, Dept of Phys Ed.

Thornton Comm Coll, South Holland III 60473

BOO Mary Richard, Dept of English, Coll of St Scholastica, Duluth Minn 55811

BOO Matilde L, Dept of Modern Lang. Univ of Miss. Univ Miss 38677

BOO Sung Lai, Dept of Soc Work, Catholic Univ of America, Wash DC 20017

BOO William O J, Dept of Chem, Univ of Miss, Univ Miss 38677

BOODEN Theodora, Dept of Microbiol. Chicago Med Sch, 2020 W Ogden Ave, Chicago III 60612

BOODEY C Webster, Dept of Poli Sci. Fashion Inst of Tech, $227 \mathrm{~W} 27 \mathrm{th} \mathrm{St}$. New York N Y 10001

BOODLEY James'W, Dept of Hort,

Cornell Univ, thaca N Y 14850

BOODNICK Allan, Dept of Fine Arts-

Comm, Cerritos Coll, 11110 E Alondra, Norwalk Cal 90650

BOODY Charies George, Dept of Mus, Austin Coll. Sherman Tex 75090 BOOE Luetta Navada, Dept of Nursing. Univ of N C, Wilmington N C 2840 .

BOOHAA Fichard K، Dept of Zool, Univ of Nebr, Lincoln Nebr 68508

BOOHER Delbert, Dept of Reproductive Biol, Case Western Heserve Univ, Cleveland Ohio 44106

BOOHER Edith Rapp. Dept of Ed, Elizabethtown Coll, Elizabethtown Pa 17022

BOOHER Edwin R. Dept of English,

Lincoln Land Comm Coll, Springfield III 62703

BOOHER Harold H, Dept of Religious Lit, Episcopal Theol Sem, Box 2247 Austin Tex 78767

BOOHER James M, Dept of Health \& Phys Ed, S D St Univ, Brookings S D 57006

BOOHEA Jerry G. Depl of Computer Technol, Scotnsdale Comm Coll, Box Y Scortsdale Ariz 85252

\section{NOW IN PRINT!}
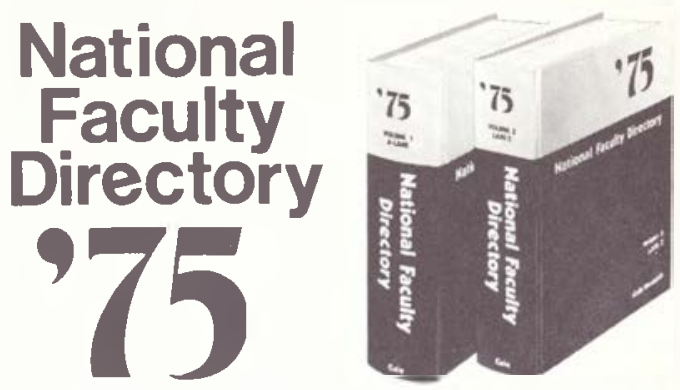

An Alphabetical List, with Addresses, of about 435,000 Members of Teaching Faculties at Junior Colleges, Colleges, and Universities in the United States and at Selected Canadian Institutions. Fifth Edition. Two Volumes. 2,327 pages. L.C. No. 76-114404. ISBN 0-8103-0652-2. $\$ 85.00 /$ set.

The National Faculty Directory is the standard reference for identifying and locating members of teaching faculties at U.S. and selected Canadian institutions of higher education. NFD-1975 is a thoroughly updated work: over 110,000 changes have been made in existing listings and about 35,000 names have been added. Each entry gives name, department, institution, and complete mailing address.

\section{REVIEWERS' COMMENTS ON PREVIOUS EDITIONS...}

CHOICE: "Clearly, this compilation is one of the most important reference works now available to the higher education academic community... An essential acquisition for all academic libraries."

AMERICAN REFERENCE BOOKS ANNUAL: "The currency of information in the present edition is considerably better than are most mailing lists distributed by some publishers and special mailing houses."

HIGHER EDUCATION BOOK REVIEW: "The National Faculty Directory is a thorough and comprehensive volume and an invaluable source material for personnel in the academic community and otherwise. $A$ 'must' reference aid in any administrative-academic office."

SCIENCE BOOKS: "This should prove to be a widely used reference in colleges, universities, public libraries, educational and professional organizations, etc. Highly recommended."

Order now to receive NFD-1975 on free 30-day approval. Receive future editions as published by placing a time saving standing order.

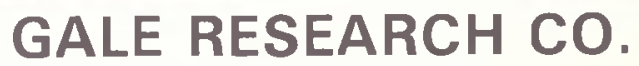

Book Tower • Detroit, Michigan 48226 
As soon as Congress votes for the appropriation, the commission will begin contacting the states through a series of meetings held in the ten federal regions (in Boston, New York, Philadelphia, Atlanta, Dallas, Kansas City, Chicago, Denver, San Francisco, Seattle, Alaska) late spring or early summer. From these meetings Trezza said he hopes to develop a preliminary document to send to each state giving the basic framework for state conferences. In turn, the states will submit their individual conference plans to the commission based on this format.

Trezza stressed that some state conferences must be held before the end of 1975 if all the states are to finish their conferences before the end of 1976. At present the commission anticipates the final White House Conference will take place in Washington during the fall of 1977. For further information please contact: NCLIS, Suite 601, 1717 K Street, NW, Washington, DC 20036; (202) 382-6595.

- The name of the Card Division of the Library of Congress was changed effective February 1 to Cataloging Distribution Service Division in order to reflect more accurately the division's present role as distributor of Librany of Concress cataloging in a variety of physical forms-MARC tapes, microforms, printed catalog cards, proofsheets, book catalogs, and technical publications. The Cataloging Distribution Service Division will be, as the Card Division has been, the channel through which the sum total of the cataloging generated, collected, and assembled at the library is made available to networks, technical processing centers, commercial processing firms, libraries, research institutes, and individual users in this country and abroad.

As the use of Library of Congress cataloging throughout the country has continued to grow, demand for the cataloging data has emphasized the need for primary, bulk distribution rather than secondary distribution in the form of individual card orders. In response to this need, the cataloging distribution service will emphasize the initial distribution of the cataloging data base to regional centers and other national network nodes for better library and information service.

The change in the name of the Card Division does not imply that the direct sale of cata$\log$ cards to libraries will be neglected. The library will continue to sell individual catalog card sets to anyone or any organization wishing to buy them, and manpower and funding for this service will be kept as high as the volume of individual card orders will support. The new name of the division will reflect its total responsibility for distributing the cataloging of the library, regardless of its physical format.

The address and telephone number of the di- vision have not been affected by the change of name. Inquiries formerly directed to the Card Division may be addressed to: Cataloging Distribution Service Division, Library of Congress, Building 159, Navy Yard Annex, Washington, DC 20541; (202) 426-6120.

- According to an announcement issued by the Committee on Accreditation of the AMErICAN Library Association, six graduate programs of library education were accredited by ALA under Standards for Accreditation, 1972 during the ALA Midwinter Meeting in Chicago. The programs are offered by the Division of Librarianship, Emory University (A. Venable Lawson, director); the Graduate School of Library Science, University of Illinois (Herbert Goldhor, director); Graduate School of Library Science, McGill University (Effe C. Astbury, director); School of Library Science, University of Michigan (Russell E. Bidlack, dean); School of Library and Information Science, State University of New York at Albany (John J. Farley, dean); and Faculty of Library Science, University of Toronto (Francess G. Halpenny, dean).

- Library administrators and personnel officers faced with the problems of serving Spanish-speaking communities will be able to discuss solutions and meet with prospective employees at the San Francisco Annual Conference. A symposium is planned for July 2, 2:004:00 p.m., and will focus upon the needs and solutions to the special problems involved in recruitment and hiring of Spanish-speaking, or Spanish-surnamed librarians. The program will be sponsored by the Reference and Adult Services Division Committee on Library Services

\section{New Art Catalog Available}

A catalog to commemorate the first exhibition in the new Gallery of the Archives of American Art, situated on the first floor of the Smithsonian Institution's National Portrait Gallery, accompanies the exhibition of letters, photographs, sketchbooks, and other documents of twenty-nine artists from the eighteenth century to the present. In an introduction to the sixty-four-page catalog, Garnett McCoy, archivist, writes: "This documentation concerns not only artists themselves, but the dealers, critics, collectors, curators, art historians, art societies, and museums as well." Available from the Archives of American Art, Smithsonian Institution, Washington, DC 20560 for $\$ 3.25$. 
to the Spanish-Speaking and REFORMA, a national organization of Spanish-speaking librarians dedicated to improving library service to the Spanish-speaking population in the United States.

Areas covered in the symposium will include ramifications of civil service regulations in minority recruitment, special category funding, and academic, school, and public library problems in meeting the goals of adequately serving the large Spanish-speaking population in the United States.

For further information contact: RASD Committee on Library Services to the SpanishSpeaking, Martha Tome, Chairperson, Columbus Memorial Library, 17th \& Constitution Avenues NW, Washington, DC 20006.

- Under the auspices of the Copyright Office of the Library of Congress and the National Commission on Libraries and Information Science, the second Conference on Resolution of Copyright Issues, held among representatives of authors, publishers, and librarians, took place on February 5, 1975, at the Smithsonian Institution, Washington, D.C. The purpose of the conference was to discuss the questions raised by library photocopying of copyrighted works and to explore possible solutions to the problem.

At the first meeting in this series on November 16,1974 , a working group was created to

\section{Need a Job?}

The Cooperative College Registry (CCR) is seeking qualified candidates for library positions. CCR, a nonprofit educational service assisting colleges and universities in their search for faculty, administrative, and support staff, reports that position openings in library science as of February 1, 1975, increased more than 40 percent over the same date last year. This increase in listings, combined with fewer available candidates in library science, documents an improved job market in the field according to CCR statistics.

CCR receives position listings throughout the year from institutions of higher education ranging in size from small private colleges to multicampus university systems. More than 90 percent of all positions listed so far this year in library science were open to candidates at the master's level.

For further information contact CCR at One Dupont Circle, Suite 10, Washington, DC 20036. explore the photocopying question in detail. This working group reported back to the conference on February 5 on the results of its interim meetings and recommended: "(a) that the Conference investigate the development of workable clearance and licensing procedures, or other procedures, applicable to library photocopying of periodical and journal articles; and (b) that the Conference direct the Working Group, or a reconstituted Working Group, to proceed with such investigation as rapidly as possible and, in this connection, authorize the Working Group to utilize such expertise as is available from organizations represented at the Conference or such other informational or technical resources at its command."

In making this recommendation, the members of the working group considered "that it was presently impossible to achieve any meaningful consensus concerning the existence of any obligation of libraries to compensate copyright proprietors for the photocopies of copyrighted periodical and journal articles made by libraries for their patrons," but that discussions could proceed with "all parties reserving their respective rights and positions as to the obligation of libraries to compensate copyright proprietors for photocopies. ..."

Following discussion of the recommendation, the conference adopted the recommendation of the working group.

Library photocopying of copyrighted works has been debated for several years. Liability for photocopying under the present copyright law is the subject of Williams of Wilkins $\mathrm{v}$. The United States, a case now pending in the Supreme Court. A complete revision of the copyright law has been proposed to Congress for many years, and the pending bills, S. 22 and HR, 2223, provide only a partial solution to the question. A National Commission on New Technological Uses of Copyrighted Works (CONTU) to be appointed by the president was authorized for a three-year period by P.L. 93-573, approved by the president on December 31, 1974. Following appointment by the president and establishment of the commission in the Library of Congress, the commission would further consider the photocopying issue. Additionally, the Senate Judiciary Subcommittee dealing with copyright reform has urged the representatives of affected (private sector) groups-authors, publishers, and librarians-to meet and work out guidelines and licensing arrangements to supplement the proposed statutory provisions in S. 22.

The current series of meetings sponsored by the Copyright Office and the NCLIS has been convened largely in response to this congressional suggestion.

The conference also considered its relationship to the National Commission on New Tech- 
nological Uses of Copyright Works. It was generally agreed that the conference could potentially assist the commission in its work and that the organizations represented might make individual presentations to the president about the composition of CONTU.

\section{P U BLICATIONS}

- The reference department of Wichita State University Library has prepared a thirtypage textbook for a basic course in bibliographical skills, which the University Library now offers. Entitled The Library Book; A Guide to How Libraries Work, the booklet presents elementary concepts and structures of bibliographical organization, such as the Library of Congress Classification, the Library of Congress call number, the idea of a bibliographic tool and of bibliographical identity, library reference service and the reference collection, as well as the library catalog. It includes, in addition, a selfguided tour of WSU Library and a short selftest. Not included is material on search strategy and organization of the literature of particular fields, since these subjects are not treated in the library's basic course.

A copy of The Library Book may be purchased by sending a check or money order for $\$ 1.00$ (handling included) to University Bookstore, CAC Building, Wichita State University, Wichita, KS 67208.

- Gale Research announces the publication of three new books:

Bibliography of Bioethics, a comprehensive annual listing of English language materials which discuss value problems in biology and medicine, is edited by LeRoy Walters, director, Center for Bioethics, the Joseph and Rose Kennedy Institute for the Study of Human Reproduction and Bioethics, Georgetown University, Washington, D.C. Both print and nonprint media are included in the bibliography. Volume one indexes newspaper and journal articles, monographs, essays within books, court decisions, state and federal laws, felons, and audiotapes. It is priced at $\$ 24.00$.

Environmental Education: A Guide to Information Sources is an annotated compilation of sources of materials, information, and support-educational, consultative, and financial-for environmental efforts at all educational levels. Compiled by William B. Stapp, professor and chairman, Environmental Education and Outdoor Recreation Program, School of Natural Resources, University of Michigan, Ann Arbor, and Mary Dawn Liston, instructor, University of North Carolina at Charlotte, the guide is the first volume in Gale's Man and the Environment Guide Series and is priced at $\$ 18.00$.

Guide to Theses and Dissertations: An International Bibliography of Bibliographies, edited by Michael M. Reynolds, School of Library and Information Services, University of Maryland, identifies and annotates more than 2,000 bibliographies concerned with theses and dissertations. The book provides a comprehensive list of resources available in individual libraries, information centers, library associations, library educational programs, and ERIC centers. It also serves as a finding guide for bibliographic and index approaches to specific subject areas. It is priced at $\$ \mathbf{4 5 . 0 0}$.

For further information on any of the above publications, contact Gale Research Company, Book Tower, Detroit, MI 48226.

- The Women and Health/Mental Health files collected by the Women's History Research Center is now available on microfilm. Thirteen reels on physical and mental health, mental illness, the life cycle, sex and sexuality, black and third world women, plus an appendix of 100 special issues of magazines are available at $\$ 30.00$ per reel. For further information contact WHRC, 2325 Oak St., Berkeley, CA 94708.

- The University of Illinois Graduate School of Library Science has recently published number 19 of its Allerton Park Institute Series, entitled CATV and Its Implications for Libraries. The ninety-one-page, indexed volume was edited by Cora E. Thomassen, associate professor in the Graduate School of Library Science at the University of Illinois, Champaign/Urbana, Illinois.

The conference theme centered on the implications of cable television for libraries. The purpose of the institute was to foster greater understanding about the subject of cable television in the conference participants.

Contributors to this volume include: Donald P. Mullally, director of broadcasting, University of Illinois; James S. Keller, director, American Television and Communications Corporation, Denver, Colorado; Edward F. Douglass, assistant professor, Department of Radio and Television, University of Illinois; Brigitte L. Kenny, assistant professor, Graduate School of Library Science, Drexel University; Lawrence W. Katz, attorney, Common Carrier Bureau, Federal Communications Commission; Ken Dowlin, director, Natrona County Public Library, Casper, Wyoming; Roberto Esteves, video coordinator, San Francisco Public Library; Bobby Mariano, regional access director, School of the Arts, New York, New York; and Russell Shank, di- 
rector of libraries, Smithsonian Institute.

The volume is available for $\$ 6.00$ from the Illini Union Bookstore, $715 \mathrm{~S}$. Wright St. Champaign, IL 61820. Standing orders for the Allerton Park Institute series can be placed at the same address. LC card number for this title is 74-620101, and ISBN is 0-87845-040-8.

- A description of the contents of the Archives of Case Memorial Library, Hartford Seminary Foundation, has been prepared for distribution under the title The Archives of Case Memorial Library.

Besides the records of Hartford Seminary Foundation, the archives also contain the papers of John Clark Archer, Joseph Bellamy, Jonathan Edwards, Jr., Duncan Black Macdonald, Asahel Nettleton, Matthew Spinka, and Henry J. Van Dyke among others. Letters, diaries, and sermons reflecting life in many areas of the world are part of this collection of over 200,000 items.

This description is available for $\$ 2.00$ from Case Memorial Library, Hartford Seminary Foundation, 55 Elizabeth St., Hartford, CT 06106 .

- The Biomedical Library of the University of Southern California has announced the publication, in November 1974, of the UCLA Biomedical Library Book Catalog, 1972-1974, edited by Ruth C. Traister. Some 6,800 items are included in this computer-generated list, which is issued in two volumes, "Authors/Titles" on 591 pages and "Subjects" on 425 pages. The project for creating the data base, from which catalog cards, acquisition lists, and book catalogs can be produced, has been supported by a grant from the National Library of Medicine.

The set of two volumes, $8 \frac{1}{2}$ by 11 inches in size, bound in paper, may be purchased at $\$ 25.00$, prepaid, from Book Catalog, Biomedical Library, Center for the Health Sciences, University of California, Los Angeles, CA 90024 . Checks should be made payable to the Regents of the University of California.

- The University of Illinois Graduate School of Library Science has recently published two items in its series of Occasional Papers.

Number 115 by Donald G. Davis, Jr., assistant professor at the University of Texas (Austin) Graduate School of Library Science, is entitled Comparative Historical Analysis of Three Associations of Professional Schools. This thirtynine-page article compares three organizations, one being the library school association, on the following characteristics: (1) purpose and goals, (2) programs of activity, (3) historical development or organization structure, (4) degree of accommodation with national practition- er associations, and (5) degree of authority over member schools.

Number 116 by Yuri Nakata and Michele Strange is a thirty-nine-page paper entitled Classification Scheme for Illinois State Publications. Librarians involved in maintaining a separate collection of state documents and also a separate federal documents collection classified by the Superintendent of Documents classification scheme will be interested in this paper. The scheme is presented in as complete a form as possible. Yuri Nakata is documents librarian, and Michele Strange is assistant documents librarian, University of Illinois at Chicago Circle Library.

Numbers in this series are available by subscription or separately. The two issues cited above are the last in the 1974 subscription, which included five numbers. Annual subscriptions for 1974 or 1975 may be placed for $\$ 5.00$; single copies are $\$ 1.00$ each prepaid. $\$ .50$ each for orders of ten or more titles. Order from: The Publications Office, 249 Armory Building, University of Illinois, Champaign, IL 61820 .

- The Institute of International and Area Studies, Western Michigan University, has recently published a book entitled Chile and Peru: Two Paths to Social Justice, as a result of a Latin American Conference held March 29-30, 1973 .

Included in the publication are papers presented at the conference by several well-known scholars. The contents include: "Peru and Chile: What Do They Imply for the United States?" by Luigi R. Einaudi; "Peruvian Paradox: Military Rule and Popular Participation" by William Foote Whyte; "Social Mobilization in Peru" by David Scott Palmer; "Social Reform in Chile under Salvador Allende" by Markos Mamalakis; "The Road to Socialism in Chile: Forces in Opposition to Structural Change" by Lynda Ann Ewen; "Agrarian Reform in Peru and Chile" by John Strasma; and "Notes toward Understanding the Church in Chile" by Harold Bradley.

This publication is edited by Dr. Leila Bradfield, chairperson of Latin American Studies at Western Michigan University. It is a paperback edition consisting of 154 pages and may be obtained from the Institute of International and Area Studies, Western Michigan University, Kalamazoo, MI 49001, for $\$ 3.11$ (postage included).

- Conservation of Colour Photographic Records is a collection of papers read to a London conference in September 1973 and is now published by the Royal Photographic Society of Great Britain. This sixty-four-page volume should be of interest to all who are concerned about using and preserving color photographs 
and color slides. In addition to the papers, the monograph includes specially commissioned reports and a short descriptive bibliography.

Prepaid orders of $\$ 10.00$ may be placed with: ARLIS/NA, P.O. Box 3692, Glendale, CA 91201.

- Teaching Creative Writing, a transcription of the proceedings of the Conference on the Teaching of Creative Writing, held at the Library of Congress on January 29 and 30, 1973, has been published by the library in paper cover and is available for sale.

Chaired by the library's 1971-73 consultant in poetry, Josephine Jacobsen, the conference convened teachers of creative writing from numerous American colleges and universities. Presenting papers and leading panel discussions were directors of the four pioneer writing programs in the United States: Elliott Coleman, founding director of the Writing Seminars at the Johns Hopkins University; Paul Engle, founder of the Writers' Workshop and now director of the International Writing Programs of the School of Letters of the University of Iowa; Wallace Stegner, founding director of the Creative Writing Center at Leland Stanford University; and John Ciardi, longtime director of the Bread Loaf Writers' Conference. Distinguished graduates of or participants in these programs served as panel members and discussed the disciplines of poetry, fiction, and nonfiction prose.

Presenting papers and chairing panels were Professor Coleman on "A Perspective of Academic Programs in Creative Writing"; Professor Engle on "The Writing of Poetry"; Professor Stegner on "The Writing of Fiction"; and Professor Ciardi on "Nonfiction Prose." Dialogue with the audience was invited following each panel discussion.

Teaching Creative Writing is available in person from the Information Counter, ground floor, Library of Congress Main Building, or by mail from the Superintendent of Documents, U.S. Government Printing Office, Washington, DC 20402. The price of the publication is $\$ 1.40$.

- The 1974 cumulative edition of the Bibliography of Alaskana is now available. This is a computer-generated keyword index to the periodical literature about Alaska based on the periodical holdings of the Rasmuson Library. The 200-page publication is priced at $\$ 6.00$ and inquiries should be addressed to Secretary, Rasmuson Library, University of Alaska, Fairbanks, AK 99701.

- The Library of Congress has published Manuscripts on Microfilm: A Checklist of Holdings in the Manuscript Division, compiled by Richard B. Bickel of the library's Manuscript
Division. This publication lists collections on microfilm, most of which are available for loan or reproduction. Over 800 entries arranged alphabetically and covering more than 10,000 reels are represented in this checklist. Included are papers of the presidents, records of foreign archives dealing with American civilization, and collections of manuscripts in the custody of the Manuscript Division, other repositories, and private hands. All of the division's collections of presidential papers will be on microfilm when the Thomas Jefferson project is completed later this year.

The copying of manuscripts relating to American history in foreign repositories began in 1905. Transcripts, photostats, and enlargement prints were made initially; however, copies made since 1935 are on microfilm. Although there are reproductions from several libraries and archives in twenty-three foreign countries, most are from the countries of Western Europe -especially Great Britain, Spain, and Francewhose colonial, diplomatic, and military activities in North America have resulted in collections of manuscripts and archives particularly rich in American materials. In most cases the items reproduced from each country are drawn from its principal repositories. The kinds of manuscripts copied are also varied. Most deal with American history in the colonial or revolutionary eras or during the first generation of the new United States. Source material for political and military history dominates, although manuscripts of value for research in economic, social, and cultural history have also been copied.

In recent years the Manuscript Division has been microfilming selected collections from its holdings for preservation and circulation purposes. The span and nature of these collections are a cross-section of the division's holdings. Microfilm publications of other repositories are acquired selectively to supplement the holdings of the Manuscript Division. Collections located in private hands are microfilmed selectively for preservation, and to supplement existing collections in the division.

Manuscripts on Microfilm is available by mail from the Superintendent of Documents, U.S. Government Printing Office, Washington, DC 20402 or in person from the Information Counter, ground floor of the Main Building of the Library of Congress. The price of this issue is $\$ 1.15$.

들

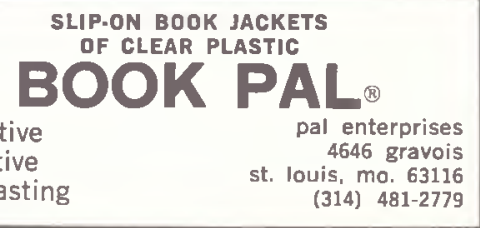




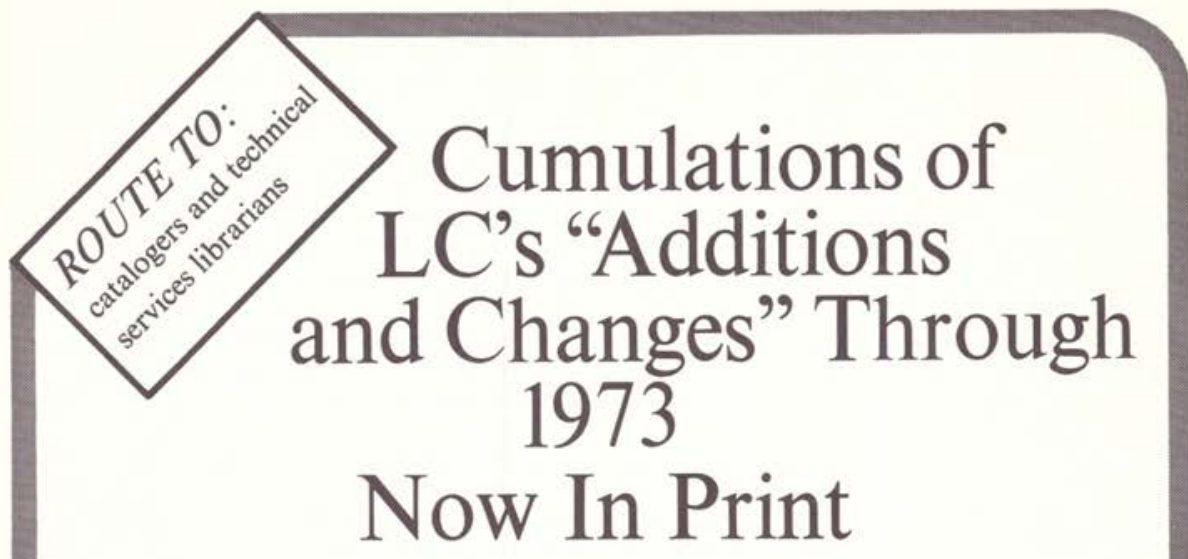

The usefulness of Gale's previous cumulations of additions and changes to Library of Congress classification schedules was praised by Jeanne Osborn in her review appearing in $R Q$ (Winter, 1973):

"Not just catalogers, but all librarians affected by the search problems involved in keeping up-to-date on LC classification are grateful for this more readily digestible bread which Gale provides us."

Users have found that the cumulations keep them abreast with the ever growing subject areas and the constantly changing theory of subject classification.

To maintain the proven usefulness of these tools, Gale has now published cumulations of additions and changes through 1973. Without these or the previous Gale cumulations,catalogers and technical services librarians wishing to check current LC cataloging practice in a subject area would have to search in as many as 45 different sources. As Ms. Osborn indicated, Gale provides a simple search formula: "We look first at the latest edition of the schedule, regardless of its reissue date, and second at the corresponding cumulation volume."

Each of the 32 cumulations contains the changes and additions for a particular schedule, in one sequence within one binding. These easy-to-use softbound cumulations cover all changes and additions between the latest editions of the basic schedules and December, 1973. Also included in the cumulations are supplementary pages bound in reprints of the basic schedules, as well as additions, eliminations, and changes of classification numbers and the subject terminology covered by these numbers. Page size, type faces, and other physical details of the Gale cumulations are identical with LC's current quarterly notices of additions and changes.

A full set of these time-saving professional tools costs \$650.00. Gale's experience with the previous cumulations shows that many libraries need more than one set. Therefore, additional sets are available for $\$ 375.00$ each. The 32 cumulations can be purchased separately-prices will be furnished on request.

Library of Congress Classification Schedules: Cumulations of Additions and Changes through 1973. Edited by Helen Savage. ISBN 0-8103-0765-0. All 32 cumulations are now in print. Please write for complete information.

\section{Gale Research Company}

Book Tower • Detroit, Michigan 48226 

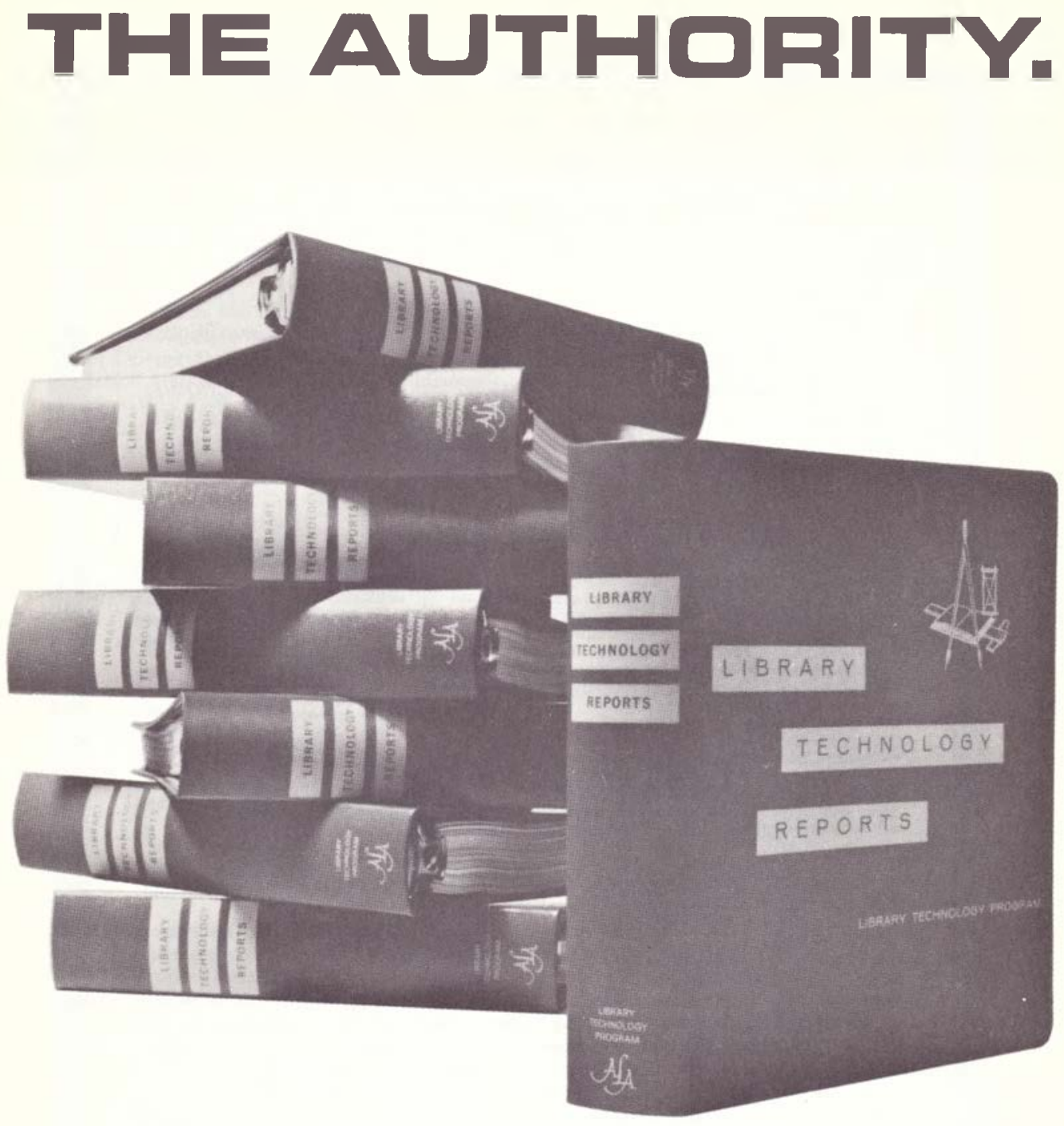

When you need objective information on library equipment, furniture, and supplies, there is only one published authority-Library Technology Reports.

Library Technology Reports is a unique bimonthly consumer publication of the American Library Association. LTR is designed to provide critical, objective evaluations of products used in libraries, media centers, and other educational institutions.
Testing and evaluation are conducted by nationally recognized independent testing laboratories and consultants, among which are R. A. Morgan Company (microform readers); United States Testing Company (audiovisual equipment); William R. Hawken Associates (microform reader/printers); and Buyers Laboratory Inc. (photocopiers, typewriters, steel library shelving, and library furniture).

For additional information and a sample issue, write to: 


\title{
As your budget gets tighter
}

\section{you need the best advice you can find.}

\author{
You just found it. Consumers Index and Media Review Digest \\ provide the advice you need, compiling evaluative information \\ on media software and equipment of value to libraries, schools, \\ and consumers. Each is the most significant reference and \\ selection tool in its field. Purchasing based on advice from \\ these works could save many times their modest cost.
}

- Digests the contents of articles from over 100 consumer interest and general information sources.

- Indexes and codes all product tests and evaluations from these sources by brand name.

- Digests the contents of new books, pamphlets and other publications related to consumerism.

- Covers cars, cameras, stereo equipment, tape recorders, boats, camping trailers, insurance, fur-nishings, and equipment for business, educational and library use, personal investments, health care and much more.

- Designed for use by the general consumer, educational institutions and business offices.

- Published quarterly and cumulated annually: Quar-terly subscription, \$25.00; Annual cumulation, $\$ 25.00 ; \quad$ Combined subscription, $\$ 45.00$

- $10 \%$ discount to libraries ordering 10 or more subscriptions direct from Pierian Press. Foreign postage extra.
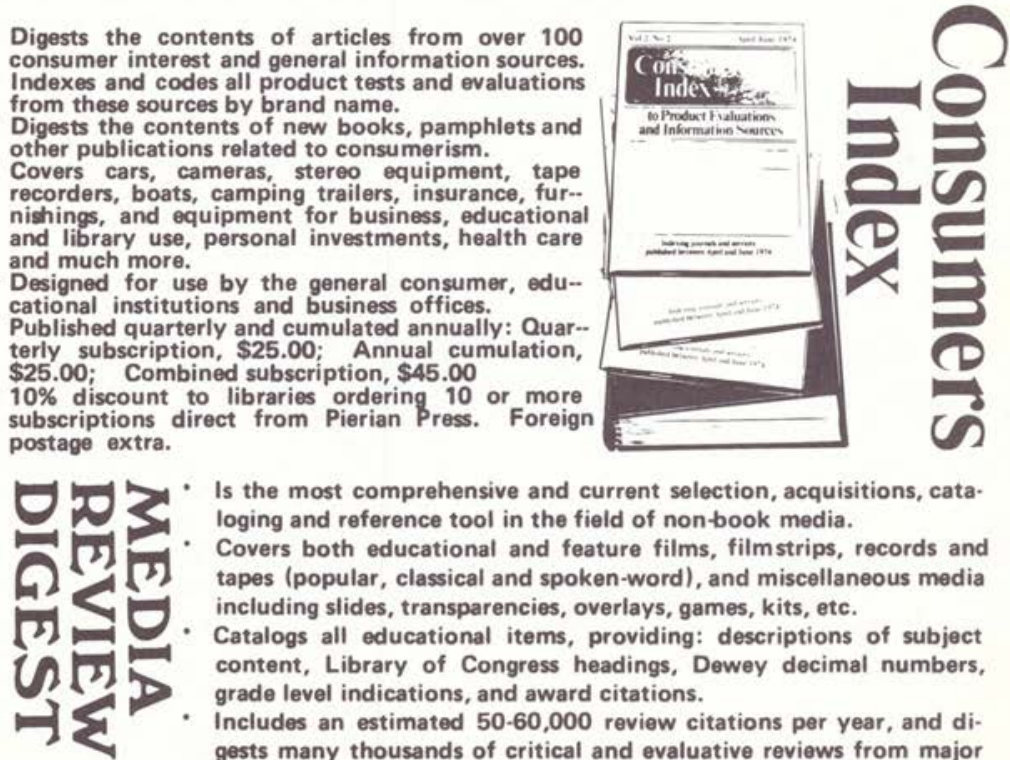

Is the most comprehensive and current selection, acquisitions, cataloging and reference tool in the field of nonbook media.

Covers both educational and feature films, filmstrips, records and tapes (popular, classical and spoken-word), and miscellaneous media including slides, transparencies, overlays, games, kits, etc.

Catalogs all educational items, providing: descriptions of subject content, Library of Congress headings, Dewey decimal numbers, grade level indications, and award citations.

Includes an estimated 50-60,000 review citations per year, and digests many thousands of critical and evaluative reviews from major reviewing sources.

- Both an alphabetical Library of Congress and a classified Dewey decimal subject approach are provided for all educational media.

- Annual cumulations are updated by quarterly supplements, all of which include subject indexes.

MRD 1973/74, \$65 plus postage. MRD 1974/75, \$65 plus postage. OTHER SUBSCRIPTION PACKAGES AVAILABLE'.

Serials Review and Reference Services Review provide similar advice on serials and reference materials. 30--day examination privileges. Send for complete information.

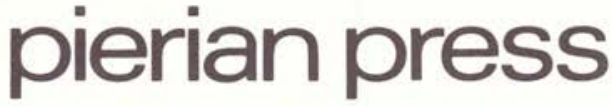

5000 washtenaw ann arbor, michigan 48106

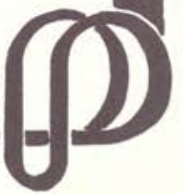

